\title{
Nesting success and productivity of the Common Barn-owl Tyto alba: results from a nest box installation and long-term breeding monitoring program in Southern Hungary ${ }^{x}$
}

\author{
László BanK ${ }^{1}$, László Haraszthy², Adrienn Horváth ${ }^{3}$ \& Győző F. \\ Horváth ${ }^{3 *}$
}

${ }^{x}$ Presented at $1^{\text {st }}$ Hungarian Owl Research Conference held in Pécs on $8^{\text {th }}$ September 2017

Received: 15 May, 2019 - Revised: May 19, 2019 -Accepted: May 21, 2019

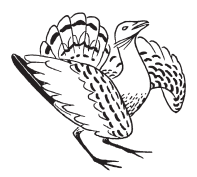

Bank, L., Haraszthy, L., Horváth, A. \& Horváth, Gy. F. 2019. Nesting success and productivity of the Common Barn-owl Tyto alba: results from a nest box installation and long-term breeding monitoring program in Southern Hungary. - Ornis Hungarica 27(1): 1-31. DOI: 10.2478/ orhu-2019-0001

\begin{abstract}
In this study, the results of a long-term nest box installation program of the Common Barn-owl Tyto alba (Scopoli, 1769) in Southern Hungary were evaluated, which program was conducted during a 24-year period (19952018). The percentages of occupied nest boxes ranged from 9.72 to $73.44 \%$ in the first breeding periods while this varied between 0 and $41.46 \%$ in the case of repeated clutches in the same nest boxes with second broods. A total of 1,265 breeding attempts were recorded including $1,020(80.63 \%)$ in the first and $245(19.36 \%)$ in the second breeding periods, from which a total of $210(16.6 \%)$ clutches did not produce any fledglings. The modal clutch size was 7 eggs in both first and second annual clutches. However, the value of productivity was higher in the case of larger clutch sizes and we found significant linear relationship between initial clutch size and fledgling production per nesting attempt in both breeding periods. Significant variation of reproductive parameters was observed among the years. The proportion of egg loss showed significant decline, while the change of hatching success and the variation of annual productivity showed significant slight positive linear trend during the 24 years. Our results suggested that despite the outlier values of reproduction characteristics in the extreme years with negative effect, a relatively stable Common Barn-owl population can be maintained by the placement of nest boxes in the investigated region.
\end{abstract}

Keywords: nest box occupancy, clutch size, eggs and hatching losses, productivity

\footnotetext{
Összefoglalás Jelen tanulmányban a gyöngybagoly, Tyto alba (Scopoli, 1769) 24 év során (1995-2018) Dél-Magyarországon megvalósított hosszú távú költőláda telepítési programjának eredményeit értékeltük. A ládafoglalási arány az első költéseknél 9,72 - 73,44\%, míg a másodköltések során ugyanabban a költőládában megismételt fészkelések aránya 0 - 41,46\% között változott. Összesen 1265 megkezdett költést, 1020 (80,63\%) első és $245(19,36 \%)$ másodköltést regisztráltunk, melyekből összesen 210 (16,6\%) költés nem produkált kirepülő fiókát. Mind az első, mind a másodköltéseknél a 7 tojásos fészekalj volt a leggyakoribb. A produktivitás értéke a nagyobb fészekalj méreteknél nagyobb volt, és mindkét költési periódusban szignifikáns lineáris összefüggést találtunk a kezdeti fészekalj méret és a megkezdett fészkelésekre vonatkozatott kirepülő fiókaprodukció között. A szaporodási paraméterek tekintetében évek közötti szignifikáns eltérést figyeltünk meg. A tojás veszteség aránya szignifikáns csökkenő, míg a kelési siker és az éves produktivitás változása enyhe, de szignifikáns pozitív trendet mutatott a 24 év során. Eredményeink azt sugallják, hogy a negatív hatású extrém években a szaporodási karakterisztikák kiugró értékei ellenére a vizsgált régióban a költőládák kihelyezésével viszonylag stabil gyöngybagoly populáció tartható fenn.
} 


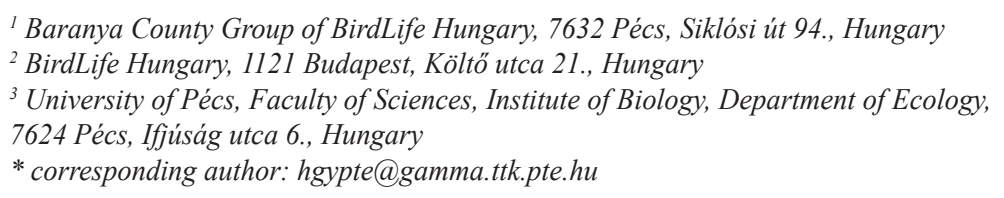

\section{Introduction}

The Common Barn-owl (Tyto alba), as a cosmopolitan nocturnal raptor is characterized with worldwide distribution because it occurs in all the continents except Antarctica (Bunn et al. 1982, Taylor 1994, Gill \& Donsker 2018). Within the areas of its range, Common Barn-owl was distributed across many biomes (continental steppes, savannas, pampas, rainforests), especially in preference to open fields and farmlands in the temperate region of South and North America as well as Europa (Taylor 1994, Roulin 2002a). As a secondary cavity-nesting bird, due to the limited availability of natural nesting and roosting sites, Common Barnowl switched to using the open man-made structures, especially church towers and traditional farm buildings (Taylor 1994, Ramsden 1998, Golawski et al. 2003, Meyrom et al. 2008, Mainwaring 2015).

Despite the wide distribution and the successful adaptation to the anthropogenic environment, the decline of local populations of Common Barn-owl was reported already from the mid-80s (Colvin 1985, Shawyer 1987, Percival 1991, de Bruijn 1994, Taylor 1994, Heath et al. 2000, Toms et al. 2001) and was confirmed by a synthesis of its population size data in many regions (BirdLife International 2004). This population decline was caused by several factors such as the loss of suitable roosting and nesting sites (Taylor 1994, Ramsden 1998, Hindmarch et al. 2012), the loss of hunting areas especially the grassland due to land use conversions and the increase in agricultural activity which has influenced the available small mammal populations as main prey groups (Colvin 1985, Taylor 1994, Love et al. 2000, Askew et al. 2007), chemical poisoning by anticoagulant rodenticide (Newton et al. 1994, Gray et al. 1994, Albert et al. 2010, Geduhn et al. 2016) as well as the mortality effect of traffic and roads (Fajardo 2001, Boves \& Belthoff 2012, Borda-de-Água et al. 2014, De Jong et al. 2018, Šálek et al. 2019).

However, numerous short and long-term studies have demonstrated that the application of nest boxes as artificial cavities is an appropriate practice to compensate for the effect of the factors causing the decrease of the populations and breeding successes (Marti et al. 1979, Johnson 1994, Leech et al. 2009, Mainwaring 2011), and to increase the pest control effect of Common Barn-owls (Meyrom et al. 2009, Kan et al. 2013, Paz et al. 2013, Kross et al. 2016, Wendt \& Johnson 2017). The costs and benefits of man-made structures as nesting sites, especially in the case of artificial nest boxes were evaluated and contested (Johnson 1994, Møller 1994, McCafferty et al. 2001, Lambrechts et al. 2010, 2012, Mainwaring 2011, 2015). Although the earlier studies demonstrated that the application of nest boxes increased the clutch size and breeding success compared to natural nesting sites (Marti et al. 1979, Johnson 1994), the advantages of nest boxes were questioned by a Hungarian study, which showed that the survival of owls differed between the artificial nest box and 
the 'natural' environment of a church tower (Klein et al. 2007). Moreover, in the case of the artificial nest box application, more species could occupy the same nest boxes which realise competitive situation or predation (Charter et al. 2010a) such as the interspecific offspring killing which was reported in the interaction between Tawny Owl (Strix aluco) and Common Barn-owl (Mátics et al. 2008).

Nesting and breeding success of Common Barn-owls were investigated from more aspects covering the impact of habitat variability, land-use and landscape context of the hunting area (Martínez \& Zuberogoitia 2004, Bond et al. 2005, Meek et al. 2009, Frey et al. 2011, Charter et al. 2012), the effect of urbanisation (Salvati et al. 2002, Hindmarch et al. 2014) and agricultural land use, such as intensive farming practise, restoration of the agricultural sector, ecological compensation areas (Leech et al. 2009, Arlettaz et al. 2010, Martin et al. 2010, Milchev \& Gruychev 2014, Almasi et al. 2015), as well as the change of population size (Toms et al. 2001, Altwegg et al. 2006a, De Jong 2009). The studies of Common Barn-owl's breeding ecology demonstrated that the reproductive output and so the local size and survival of its populations were determined basically by habitat and nest-site qualities (Gubanyi et al. 1992, Bond et al. 2005, Frey et al. 2011), food supply, in particular the availability and density fluctuation of main prey species or groups (Taylor 1994, Klok \& de Roos 2007, Charter et al. 2015, Pavluvčík et al. 2015), and weather conditions (Chausson et al. 2014a, Charter et al. 2017) especially extreme winters (Marti \& Wagner 1985, 1997, Taylor 1992, Marti 1994, Altwegg et al. 2006b, Chausson et al. 2014b). The reproductive success of Common Barn-owls was investigated at the border of its distribution range where the lifetime productivity was determined significantly by winter weather, particularly the additive effect of cold temperature and the higher snow cover (Marti 1994, 1997, Tóth et al. 2004). Due to a severe winter, a large decline in the effective number of Common Barn-owls can lead to genetic bottlenecks, which has been investigated in a local population in Hungary (Mátics et al. 2017).

Clutch size, as one of the most important life history traits of birds (Lack 1947, Stearns 1976, Price \& Liou 1989), has been assessed in detail in the breeding ecology of Common Barn-owls such as the comparison of first, replacement and second clutches (Marti 1994, Martínez \& López 1999, Frey et al. 2011), seasonal (Baudvin 1986, Marti 1994, Roulin 2002b) and annual variation (Martínez \& López 1999, Toms et al. 2001), and in relation to the abundance of main prey (Taylor 1994, Pavluvč́k et al. 2015). Nevertheless, the variation of breeding characteristics related to initial clutch size and relationship between clutch size and productivity were evaluated only in a few studies on Common Barn-owls (Wilson et al. 1986, Johnson 1994, Martínez \& López 1999). Lack $(1947,1954)$ proposed that clutch size corresponds to maximum number of young that parents can rear, and as the consequence of natural selection, the most productive clutch size is the most frequent. In contrast, numerous studies of birds demonstrated that the most frequent clutch size is smaller than the most productive which was determined by a trade-off between clutch size and future reproductive success (Stearns 1976, Partridge \& Harvey 1988, Godfray et al. 1991). However, modal clutch size was the most productive clutch in case of Common Barn-owls in the Mediterranean region, and no significant variation was found between years in the average clutch size (Martínez \& López 1999). 
Birds of prey and owls, particularly Common Barn-owls were characterised by hatching asynchrony, which is an adaptive breeding strategy for producing marginal offspring (Clark \& Wilson 1981, Stoleson \& Beissinger 1995) and causes intra-brood size hierarchy and conflict (Viñuela 1999, 2000, Roulin et al. 1999, 2004). Numerous hypotheses have been proposed to explain asynchronous hatching (Clark \& Wilson 1981, Stenning 1996). According to the 'brood reduction hypothesis' (Lack 1954), hatching asynchrony is an adaptive trait resulted in the mortality of the smallest offspring when food supply is low and not enough for parents to raise all hatchlings. In case of Common Barn-owl, the 'sibling negotiation hypothesis' was developed to understand the mechanism of competition between nestlings of different age, which highlighted the importance of nutritional need asymmetry between siblings (Roulin 2002b, 2004). Although the smaller nestlings can compensate their weaker competitive ability through the negotiation mechanism (Roulin 2004), the occurrence of brood reduction is frequent in the case of Common Barnowls (Taylor 1994, Roulin 2002c), which can be realised in different behavioural mechanisms, such as lethal attacks on smaller siblings or siblicide (Mock 1985) and cannibalism (Baudvin 1978, Hamilton 1980, Roulin \& Dreiss 2012). Furthermore, the results of video observation suggested that the risk of brood reduction increases as the female starts foraging after hatching, since access to food is reduced for the youngest nestling (Durant et al. 2004). It has also been proposed that the Common Barn-owl's female adjusts clutch size to the male's efficiency to feed the nestlings and herself in order to optimise fledging success (Durant et al. 2010). The level of brood reduction is an important and measurable feature of Common Barn-owls' breeding biology (Hindmarch et al. 2014) which can significantly influence reproductive success.

The objectives in this study are to evaluate the results of a long-term Common Barn-owl nest box installation and monitoring program in Southern Hungary, examining the variation of observed and calculated breeding characteristics, comparing first and second annual clutches (1), the relationship between clutch size and breeding success focusing on productivity (2) and the multi-annual change of reproductive output (3).

\section{Material and methods}

\section{Study area, nest box installation and control protocol}

Nest box installation and the breeding monitoring of Common Barn-owl was carried out in Baranya county $\left(4429.6 \mathrm{~km}^{2}\right)\left(46^{\circ} 04^{\prime} \mathrm{N}, 18^{\circ} 14^{\prime} \mathrm{E}\right)$ which is situated in the south-eastern part of the Transdanubian region in Southern Hungary. The environmental conditions of this county are favourable for Common Barn-owls. The climate is determined by Mediterranean and sub-Mediterranean effect and is characterized by a high number of sunshine hours, relatively low fluctuations of temperatures and mild winters. Due to relatively high winter temperatures, the number of snow-covered days are low. The spatial structure of the county is characterized with a multitude of small villages, with 301 settlements altogether that actually represent 340 separate units of built and populated surface. The average administrative 


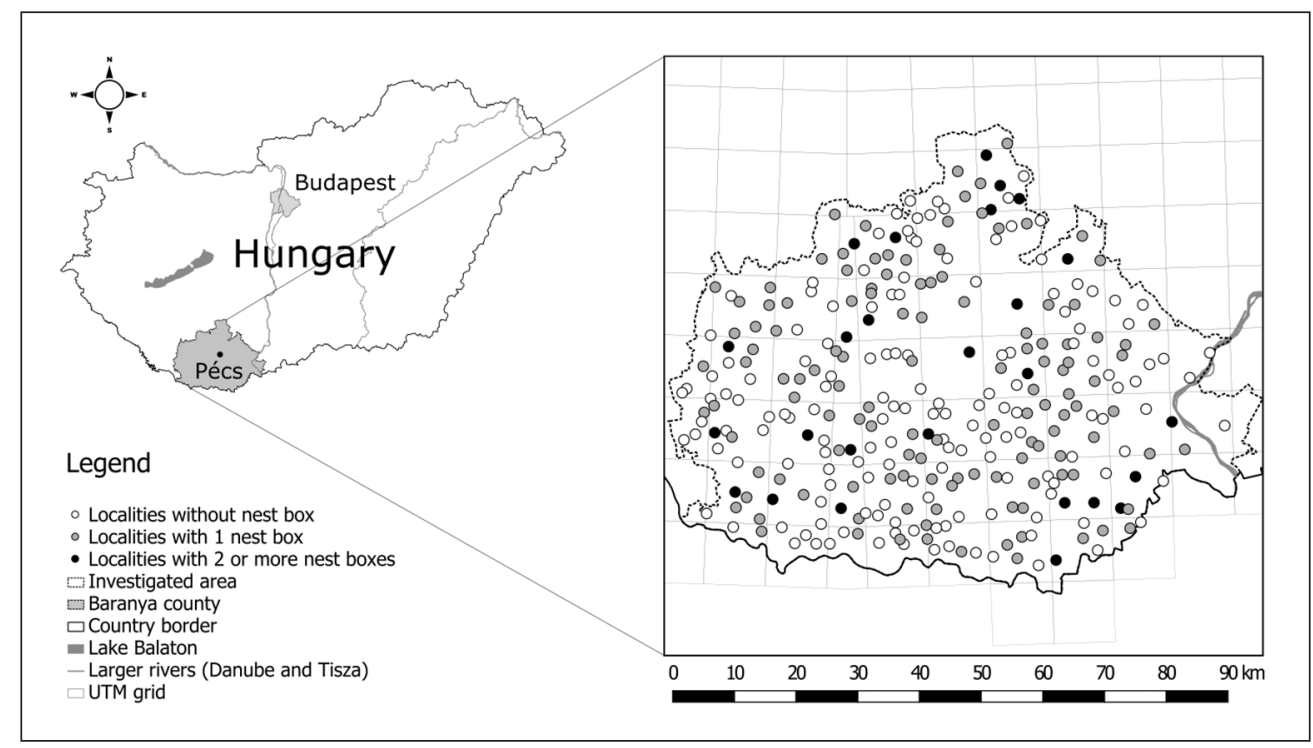

Figure 1. Spatial distribution of installed Common Barn-owl nest boxes in South-Hungary, Baranya County

1. ábra A kihelyezett gyöngybagoly költőládák térbeli eloszlása Dél-Magyarországon, Baranya megyében

area of the villages slightly exceeds 1,500 hectares. In $96 \%$ of the settlements, at least one church tower or chapel can be found and $21 \%$ have more such buildings.

A total of 163 nest boxes were placed in different buildings $(95 \%$ in church towers, $5 \%$ in chapels and lofts of farm buildings) progressively from 1995 to 2018 . The nest boxes were placed in a total of 150 settlements, $82 \%$ of which had one and $18 \%$ had more than one boxes (Figure 1). The number of available nest boxes for Common Barn-owls in the consecutive years was determined by the number of installed new and removed nest boxes (due to dilapidation of boxes and church tower renovation). During the monitoring period, the number of settlements as nest site localities varied between 41 and 137 (108.16 \pm 5.47 per year).

Nest boxes, measuring $100 \times 50 \times 50 \mathrm{~cm}$ were made from good quality pine boards, with a $15 \times 15 \mathrm{~cm}$ entrance, a partition wall in the middle and a removable roof. The orientation of nest boxes within the towers was determined by the location of bell structures (racks, bins). Depending on these, the direction of east was preferred at the installation of net boxes. If this was not possible, the nest box was placed with western, southern or occasionally northern orientation. In the latter case, a dividing wall was built in the nest box for wind protection. In church towers, chapels and farm buildings nest boxes were placed 20-40 m and 4-10 m high, respectively.

During the 24 years, the nest boxes were regularly visited in the breeding season including first and second annual clutches to determine whether they were occupied or not by breeding pairs. Criterions of controls were determined by climate condition of Baranya county and life-history strategies and traits of Common Barn-owl. During the monitoring periods, the first visits were conducted between 1-15 April. However, the controls were started 8-10 days earlier after a mild winter. In the case of non-occupied nest boxes, controls were carried 
out until mid-September (4-5 times a year) and in the case of occupied nest boxes until the end of the second clutches, usually until mid-October. During the 24-year monitoring program, nest box checkings were implemented by volunteers (50-60 people) of the Baranya County Group of BirdLife Hungary based on a protocol developed for this purpose. The data were sent to the coordinator after each control. The date of the next visit was determined from the conditions observed at the first occasion (empty nest box, eggs, etc.). In addition, to evaluate the diet composition of Common Barn-owl pairs, pellet samples were collected from the nest boxes each time a control visit was executed.

\section{Observed and calculated breeding parameters}

At each sampling locality, the presence/absence of Common Barn-owls and their breeding status were recorded. Nest boxes in which at least one egg was found, were considered 'occupied' (active nest) (Steenhof 1987, Charter et al. 2010b, Frey et al. 2011). The proportion of nest box occupancy was calculated from the number of occupied nest boxes in the first annual clutches, while in the second annual breeding seasons, this proportion was obtained relative to the occupied nest boxes by breeders of the first annual clutches. Furthermore, occupancy rate was calculated in the case of the breeding pairs which occupied a nest box and laid eggs only in the second annual breeding periods. Based on the total number of breeding attempts, nesting success was calculated as the proportion of pairs that raised at least one fledgling, and the percentage of unsuccessful pairs was also determined (Steenhof $\&$ Newton 2007). The following breeding parameters were recorded: clutch size, brood size at hatching and fledging. To determine reproduction loss, two more parameters were calculated: the number and proportion of unhatched eggs and brood reduction. Hatching success was calculated as the percentage of eggs that hatched within each clutch, and fledging success was obtained as the percentage of young that fledged from each brood. Reproductive success was calculated as the percentage of fledged young per eggs from each successful nest. In addition, productivity was defined as the rate of the number of fledglings per nesting attempts (Martínez \& López 1999, Steenhof \& Newton 2007) or per all observed breeding pairs (including unsuccessful breeders) which, as standardized fledging success value (Sasvári \& Hegyi 2011, Hindmarch et al. 2014), is suitable for comparing productivity between different clutch sizes and years. In the first step, productivity was calculated from the number of young produced in all successful nests and from the cumulative number of fledglings considering initial clutch size. Secondly, annual productivity was determined from the pooled quantity of fledglings and nesting attempts of different years.

\section{Statistical methods}

The results of nest box occupancy and proportion of occupied boxes were presented as range and mean \pm SE from the first annual clutches, both in case of occupied nest boxes where the clutches were repeated by the nesting pairs and in case of nest boxes were the clutches were detected only in the second annual breeding periods. To assess the statistical difference of clutch failure and nesting success proportions between the first and second annual 
clutches, chi-square test was applied in the software $\mathrm{R}$ with the command prop.test. As regards all successful nests, the amount of all breeding parameters per nest and per year are presented as range and mean \pm SE from the first and second annual clutches as well as from the whole annual breeding period, respectively. The distribution of clutch size, brood size, fledglings and annual productivity were represented with histograms and overlaid smoothed histograms with first and second order smoother in case of first and second annual clutches and total breeding seasons, respectively.

According to initial clutch sizes for which the exact reproductive history was detected, the cumulative number of breeding parameters, the percentage value of different successes and the calculated productivity rate as well as their mean and $95 \%$ confidence interval were presented in tables (clutch sizes only occurring once were excluded from the assessment) separately for the first and second annual breeding season. Considering different clutch sizes, the prop.test function was used to evaluate the difference in the proportion of unhatched eggs and brood reduction between the first and second annual breeding season, as well as in comparison of the proportion of egg and nestling losses within the given breeding periods. Boxplots (mean \pm SE, lower and upper limits of $95 \%$ confidence interval) were used to present the annual variation of observed and calculated breeding parameters. The standard error and $95 \%$ confidence interval of mean were calculated in R using the 'Plotrix' (Lemon 2006) and 'Rmisc' (Hope 2016) package.

Mann-Whitney's U-test and the Kruskal-Wallis test (followed by Dunn's post hoc test for multiple comparisons) were used to compare the amount of breeding parameters between the first and second annual clutches and among the different years, respectively (Zar 2010).

Based on the data of all successful nests, linear regression method was used to assess the relationship between clutch size and productivity. Furthermore, linear regression was performed also to analyse the trend of variation of unhatched eggs, hatching success and annual productivity for the period 1995-2018. All statistical analyses were conducted in the R v3.4.0 environment ( $R$ Core Team 2017). Statistical tests were considered as significant at the level $\mathrm{P} \leq 0.05$ as standard in all analyses (Sokal \& Rohlf 1997).

\section{Results}

\section{Nest box occupancy, number of breeding attempts and nesting success}

During the 24 years, the total number of installed nest boxes varied between 43 and 163 $(126.58 \pm 6.91$ per year) while nest box occupation ranged from 7 to $94(42.5 \pm 4.29$ per year) in the first annual clutches. Considering Common Barn-owl pairs which occupied successfully a nest box in the first annual breeding season, the clutches were repeated in 2 to 26 nest boxes $(8.37 \pm 1.46$ per year) in the second nesting periods. The number of boxes where the clutches were produced only in the second annual breeding seasons ranged from 1 to 11 (1.83 \pm 0.54 per year). The percentage of occupied nest boxes ranged from 9.72 to $73.44 \%$ $(34.22 \pm 3.37 \%)$ in the first breeding periods, while the proportion of occupied nest boxes in the second annual clutches relative to the cumulative number of first nest box occupancy 
varied between $0 \%$ and $41.46 \%(18.58 \% \pm 2.17 \%)$. In the case of breeding pairs for which nesting was detected only in the second annual periods, nest box occupancy rate varied between $0 \%$ and $9.02 \%(1.66 \% \pm 0.47 \%)$.

Based on the results of nest box occupancy, 1,265 breeding attempts were recorded including 1,020 (80.63\%) nesting attempts in the first and $245(19.37 \%)$ in the second breeding

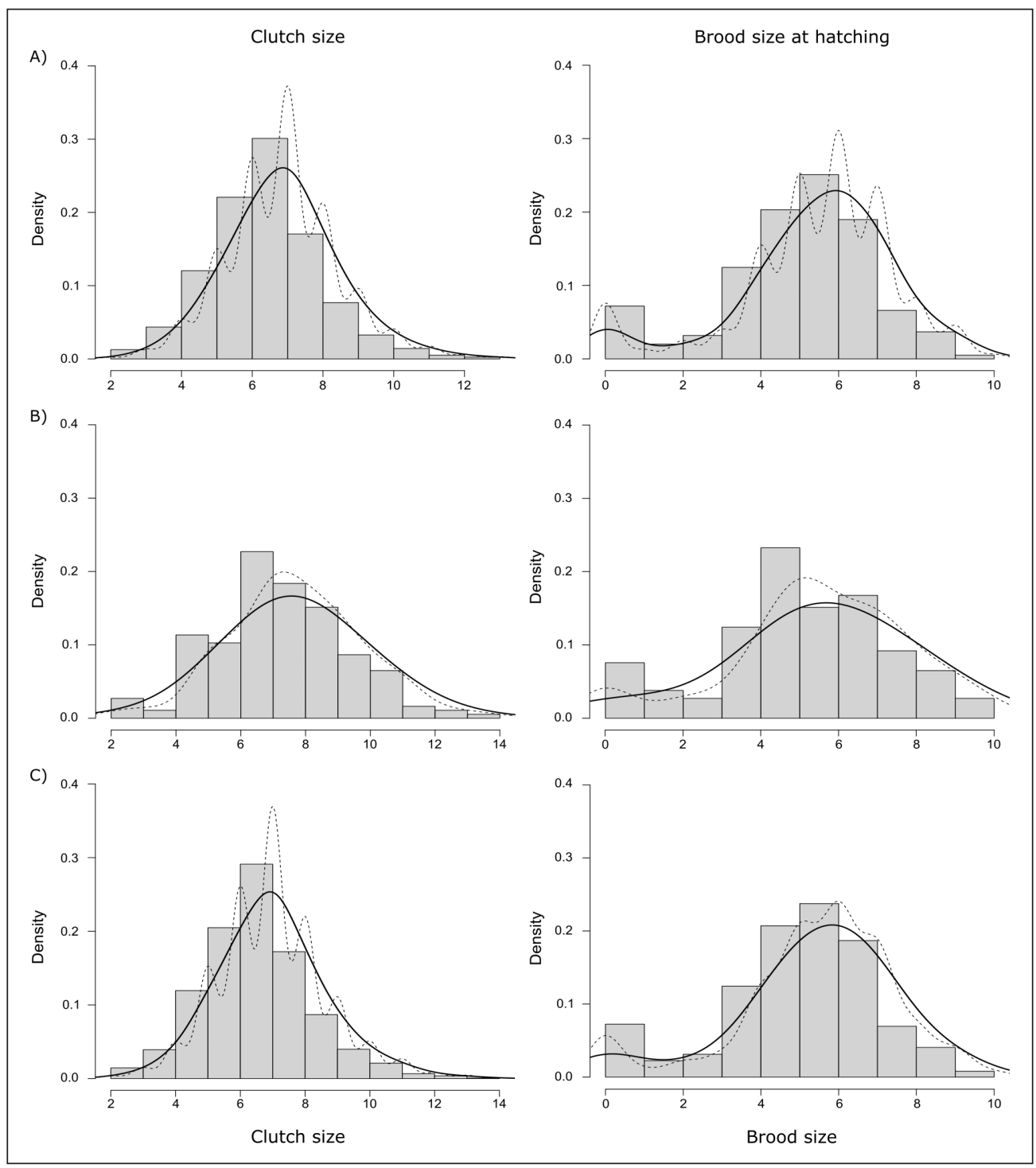

Figure 2. Histograms and smoothed histograms with first (dashed line) and second (solid line) order smoother of clutch size and brood size distribution in the first (A) and second (B) annual clutches as well as in whole breeding period (C)

2. ábra A fészekalj nagyság és a kikelt fiókaszám eloszlásának hisztogramja és simított hisztogramja első (szaggatott vonal) és másodrendű (folytonos vonal) simítással az első- (A) és másodköltés (B) esetén, valamint a teljes szaporodási időszakban (C) 
periods. From the total number of breeding attempts, $210(16.6 \%)$ clutches did not produce any fledglings. Comparing the two annual nesting periods, the percentage of clutch failure was almost similar: $16.17 \%$ (165 out of 1,020 clutches) of the first and 18.37\% (45 out of 245 clutches) of the second annual clutches did not produce fledglings. Thus, calculated nesting success was $83.39 \%$ (1055 productive clutches out of 1,265 nesting attempts) in the case of the total annual breeding season while $83.82 \%$ ( 855 out of 1,020 nesting attempts) of the first annual clutches and $81.63 \%$ (200 out of 245 nesting attempts) of the second annual clutches were successful where at least one young was produced by the breeding pairs. In the case of both successful and failed clutches, the number of nestlings did not differ from a homogeneous distribution in the comparison of the two annual breeding periods $\left(\chi^{2}=0.53, P=0.464\right)$.

\section{Clutch size, brood size and hatching success}

From the total of 1,265 breeding attempts, 982 clutches $(N=797$ for first and $N=185$ for second annual clutches) were recorded where the complete reproductive history was known. Based on the sample size, the average size per nest of first clutches was $6.84 \pm 0.05$ eggs,

Table 1. Cumulative number and percentage value of Common Barn-owl breeding parameters in relation to initial clutch size for clutches where complete reproduction history was detected in the first annual breeding period

1.táblázat A gyöngybagoly költési paramétereinek összesített és százalékos értéke a kezdeti fészekalj méretek függvényében, melyeknél detektáltuk a teljes reprodukciós történetet az első költés időszakában

\begin{tabular}{|c|c|c|c|c|c|c|c|c|c|c|c|c|}
\hline \multirow{2}{*}{ 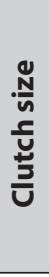 } & \multirow{2}{*}{ 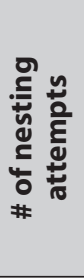 } & \multirow{2}{*}{ 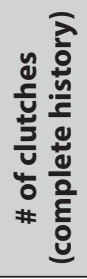 } & \multirow{2}{*}{ 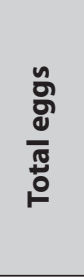 } & \multicolumn{2}{|c|}{$\begin{array}{c}\text { Unhatched } \\
\text { eggs }\end{array}$} & \multicolumn{2}{|c|}{$\begin{array}{c}\text { Eggs } \\
\text { hatched }\end{array}$} & \multicolumn{2}{|c|}{$\begin{array}{l}\text { Brood } \\
\text { reduction }\end{array}$} & \multicolumn{2}{|c|}{$\begin{array}{l}\text { Young } \\
\text { fledged }\end{array}$} & \multirow{2}{*}{ 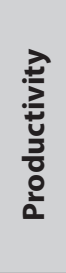 } \\
\hline & & & & $n$ & $\%$ & $n$ & $\%$ & $n$ & $\%$ & $n$ & $\%$ & \\
\hline 2 & 1 & 1 & 2 & 2 & 100 & 0 & 0 & 0 & 0 & 0 & 0 & 0 \\
\hline 3 & 9 & 7 & 21 & 7 & 33.33 & 14 & 66.67 & 3 & 21.43 & 11 & 78.57 & 1.56 \\
\hline 4 & 37 & 36 & 144 & 28 & 19.44 & 116 & 80.56 & 29 & 25.00 & 87 & 75.00 & 3.14 \\
\hline 5 & 106 & 97 & 485 & 96 & 19.79 & 389 & 80.21 & 47 & 12.08 & 342 & 87.92 & 3.67 \\
\hline 6 & 210 & 184 & 1104 & 170 & 15.40 & 934 & 84.60 & 158 & 16.92 & 776 & 83.08 & 4.45 \\
\hline 7 & 272 & 240 & 1680 & 338 & 20.12 & 1342 & 79.88 & 235 & 17.51 & 1107 & 82.49 & 4.93 \\
\hline 8 & 161 & 130 & 1040 & 221 & 21.25 & 819 & 78.75 & 156 & 19.05 & 663 & 80.95 & 5.09 \\
\hline 9 & 77 & 61 & 549 & 110 & 20.04 & 439 & 79.96 & 82 & 18.68 & 357 & 81.32 & 5.70 \\
\hline 10 & 32 & 28 & 280 & 88 & 31.43 & 192 & 68.57 & 23 & 11.98 & 169 & 88.02 & 6.00 \\
\hline 11 & 8 & 8 & 88 & 37 & 42.05 & 51 & 57.95 & 5 & 9.80 & 46 & 90.20 & 6.38 \\
\hline 12 & 4 & 4 & 48 & 29 & 60.42 & 19 & 39.58 & 3 & 15.79 & 16 & 84.21 & 4.75 \\
\hline 13 & 1 & 1 & 13 & 4 & 30.77 & 9 & 69.23 & 0 & 0 & 9 & 100 & 9 \\
\hline
\end{tabular}


Table 2. Cumulative number and percentage value of Common Barn-owl breeding parameters in relation to initial clutch size for clutches where complete reproduction history was detected in the second annual breeding period

2. táblázat $A$ gyöngybagoly költési paramétereinek összesített és százalékos értéke a kezdeti fészekalj méretek függvényében, melyeknél detektáltuk a teljes reprodukciós történetet a másodköltés időszakában

\begin{tabular}{|c|c|c|c|c|c|c|c|c|c|c|c|c|}
\hline \multirow{2}{*}{$\begin{array}{l}\frac{\tilde{N}}{n} \\
\frac{5}{u} \\
\frac{3}{3}\end{array}$} & \multirow{2}{*}{ 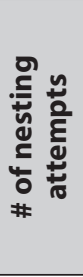 } & \multirow{2}{*}{ 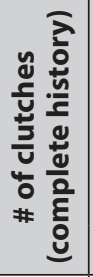 } & \multirow{2}{*}{$\begin{array}{l}\text { ŏ } \\
\frac{0}{0} \\
\frac{1}{0}\end{array}$} & \multicolumn{2}{|c|}{$\begin{array}{c}\text { Unhatched } \\
\text { eggs }\end{array}$} & \multicolumn{2}{|c|}{$\begin{array}{c}\text { Eggs } \\
\text { hatched }\end{array}$} & \multicolumn{2}{|c|}{$\begin{array}{l}\text { Brood } \\
\text { reduction }\end{array}$} & \multicolumn{2}{|c|}{$\begin{array}{l}\text { Young } \\
\text { fledged }\end{array}$} & \multirow{2}{*}{ 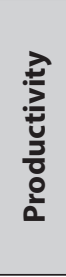 } \\
\hline & & & & $n$ & $\%$ & $n$ & $\%$ & $n$ & $\%$ & $n$ & $\%$ & \\
\hline 2 & 2 & 2 & 4 & 0 & 0 & 4 & 100 & 0 & 0 & 4 & 100 & 2 \\
\hline 3 & 3 & 3 & 9 & 2 & 22.22 & 7 & 77.78 & 3 & 42.86 & 4 & 57.14 & 1.33 \\
\hline 4 & 3 & 2 & 8 & 4 & 50 & 4 & 50 & 1 & 25 & 3 & 75 & 1 \\
\hline 5 & 22 & 21 & 105 & 31 & 29.52 & 74 & 70.48 & 18 & 24.32 & 56 & 75.68 & 2.55 \\
\hline 6 & 23 & 19 & 114 & 21 & 18.42 & 93 & 81.58 & 20 & 21.51 & 73 & 78.49 & 3.17 \\
\hline 7 & 51 & 42 & 294 & 99 & 33.67 & 195 & 66.33 & 65 & 33.33 & 130 & 66.67 & 2.55 \\
\hline 8 & 40 & 34 & 272 & 59 & 21.69 & 213 & 78.31 & 44 & 20.67 & 169 & 79.34 & 4.23 \\
\hline 9 & 30 & 28 & 252 & 77 & 30.56 & 175 & 69.44 & 36 & 20.57 & 139 & 79.43 & 4.63 \\
\hline 10 & 18 & 16 & 160 & 45 & 28.13 & 115 & 71.88 & 23 & 20 & 92 & 80 & 5.11 \\
\hline 11 & 14 & 12 & 132 & 39 & 29.55 & 93 & 70.45 & 16 & 17.2 & 77 & 82.8 & 5.5 \\
\hline 12 & 3 & 3 & 36 & 10 & 27.78 & 26 & 72.22 & 1 & 3.85 & 25 & 96.15 & 8.33 \\
\hline 13 & 2 & 2 & 26 & 16 & 61.54 & 10 & 38.46 & 2 & 20 & 8 & 80 & 4 \\
\hline 14 & 1 & 1 & 14 & 7 & 50 & 7 & 50 & 1 & 14.29 & 6 & 85.71 & 6 \\
\hline
\end{tabular}

$7.71 \pm 0.15$ eggs for second clutches and $7.01 \pm 0.05$ eggs for the total annual breeding periods. The relative frequency distribution of clutch size and brood sizes at hatching observed during the monitoring period are given in Figure 2. Both in first and second clutches as well as in the case of all clutches, modal clutch size was 7 eggs which was detected with highest frequency (first annual clutches: $30.11 \%$, second clutches: $22.7 \%$, the entire annual periods: $28.72 \%$ of clutches) (Figure 2). Although modal clutch size was equal in both nesting periods, clutches of 6 eggs were detected with the second highest frequency in the first annual clutches $(23.09 \%)$, while the clutches of 8 eggs were also characterized with higher proportion in the second clutches (18.38\%). The clutches of 6-7 eggs were typical for $53.2 \%$ of total clutches in the first and clutches of 7-8 eggs were typical for $41.08 \%$ of total clutches in the second nesting periods (Figure 2). As a result we found significant difference in clutch size between first and second annual clutches (Mann-Whitney U-test: $Z=5.66, P<0.001$ ).

The numbers of unhatched eggs per nest ranged from 0 to $13(1.57 \pm 0.06)$ in the total annual breeding season while it changed between 0 and $12(1.42 \pm 0.07)$ in the first and 0 to $13(2.22$ $\pm 0.15)$ in the second annual clutches. The loss of eggs was significantly higher in the first than in the second annual nesting period (Mann-Whitney U-test: $Z=5.65, P<0.001$ ). In the case 
Table 3. Variation of the main and $95 \%$ confidence interval of breeding parameters in relation to initial clutch size for clutches where complete reproduction history was known in the first annual breeding period

3. táblázat A költési paraméterek átlag és 95\%-os konfidencia intervallum értékeinek eltérése a kezdeti fészekalj méretek függvényében, melyeknél ismert a teljes reprodukciós történet az első költés időszakában

\begin{tabular}{|c|c|c|c|c|c|c|c|c|c|c|c|c|}
\hline \multirow{2}{*}{$\begin{array}{l}\frac{N}{n} \\
\frac{N}{U} \\
\frac{n}{3} \\
\text { Un }\end{array}$} & \multicolumn{2}{|c|}{$\begin{array}{l}\text { Unhatched } \\
\text { eggs }\end{array}$} & \multicolumn{2}{|c|}{$\begin{array}{c}\text { Eggs } \\
\text { hatched }\end{array}$} & \multicolumn{2}{|c|}{$\begin{array}{l}\text { Brood } \\
\text { reduction }\end{array}$} & \multicolumn{2}{|c|}{$\begin{array}{l}\text { Young } \\
\text { fledged }\end{array}$} & \multicolumn{2}{|c|}{$\begin{array}{l}\text { Reproductive } \\
\text { success }\end{array}$} & \multicolumn{2}{|c|}{ Productivity } \\
\hline & $\overline{\boldsymbol{x}}$ & $\mathrm{Cl}$ & $\overline{\boldsymbol{x}}$ & $\mathrm{Cl}$ & $\overline{\boldsymbol{x}}$ & $\mathrm{Cl}$ & $\overline{\boldsymbol{x}}$ & $\mathrm{Cl}$ & $\overline{\boldsymbol{x}}$ & $\mathrm{Cl}$ & $\overline{\boldsymbol{x}}$ & $\mathrm{Cl}$ \\
\hline 3 & 1.00 & $\begin{array}{l}-0.07- \\
2.07 \\
\end{array}$ & 2.00 & $\begin{array}{l}0.93- \\
3.07\end{array}$ & 0.43 & $\begin{array}{c}-0.30- \\
1.16 \\
\end{array}$ & 1.57 & $\begin{array}{l}0.40- \\
2.75\end{array}$ & 52.38 & $\begin{array}{l}13.16- \\
91.61 \\
\end{array}$ & 1.07 & $\begin{array}{l}0.30- \\
1.85 \\
\end{array}$ \\
\hline 4 & 0.78 & $\begin{array}{l}0.35- \\
1.21\end{array}$ & 3.22 & $\begin{array}{l}2.79- \\
3.65\end{array}$ & 0.81 & $\begin{array}{l}0.35- \\
1.25\end{array}$ & 2.42 & $\begin{array}{l}1.86- \\
2.97\end{array}$ & 60.42 & $\begin{array}{l}46.50- \\
74.33\end{array}$ & 1.89 & $\begin{array}{l}1.45- \\
2.33\end{array}$ \\
\hline 5 & 0.99 & $\begin{array}{l}0.69- \\
1.29 \\
\end{array}$ & 4.01 & $\begin{array}{l}3.71- \\
4.31\end{array}$ & 0.48 & $\begin{array}{l}0.28- \\
0.69\end{array}$ & 3.53 & $\begin{array}{l}3.19- \\
3.86 \\
\end{array}$ & 70.52 & $\begin{array}{l}63.83- \\
77.20 \\
\end{array}$ & 2.74 & $\begin{array}{l}2.47- \\
3.02 \\
\end{array}$ \\
\hline 6 & 0.92 & $\begin{array}{l}0.71- \\
1.13\end{array}$ & 5.08 & $\begin{array}{l}4.87- \\
5.29\end{array}$ & 0.86 & $\begin{array}{l}0.66- \\
1.06\end{array}$ & 4.22 & $\begin{array}{l}3.95- \\
4.49 \\
\end{array}$ & 70.29 & $\begin{array}{l}65.80- \\
74.78\end{array}$ & 3.36 & $\begin{array}{l}3.16- \\
3.59\end{array}$ \\
\hline 7 & 1.41 & $\begin{array}{l}1.18- \\
1.63\end{array}$ & 5.59 & $\begin{array}{l}5.37- \\
5.82\end{array}$ & 0.98 & $\begin{array}{l}0.82- \\
1.14\end{array}$ & 4.61 & $\begin{array}{l}4.37- \\
4.85\end{array}$ & 65.89 & $\begin{array}{l}62.47- \\
69.31\end{array}$ & 3.66 & $\begin{array}{l}3.47- \\
3.86\end{array}$ \\
\hline 8 & 1.70 & $\begin{array}{l}1.38- \\
2.02 \\
\end{array}$ & 6.30 & $\begin{array}{l}5.98- \\
6.62 \\
\end{array}$ & 1.20 & $\begin{array}{l}0.94- \\
1.46 \\
\end{array}$ & 5.10 & $\begin{array}{l}4.75- \\
5.45 \\
\end{array}$ & 63.75 & $\begin{array}{l}59.42- \\
68.08 \\
\end{array}$ & 4.12 & $\begin{array}{l}3.83- \\
4.40 \\
\end{array}$ \\
\hline 9 & 1.80 & $\begin{array}{l}1.22- \\
2.39\end{array}$ & 7.20 & $\begin{array}{l}6.61- \\
7.78\end{array}$ & 1.34 & $\begin{array}{l}0.89- \\
1.80\end{array}$ & 5.85 & $\begin{array}{l}5.22- \\
6.49\end{array}$ & 65.03 & $\begin{array}{l}57.96- \\
72.09\end{array}$ & 4.69 & $\begin{array}{c}4.16- \\
5.22 \\
\end{array}$ \\
\hline 10 & 3.14 & $\begin{array}{l}2.12- \\
4.17 \\
\end{array}$ & 6.86 & $\begin{array}{l}5.93- \\
7.99 \\
\end{array}$ & 0.82 & $\begin{array}{l}0.83- \\
1.32 \\
\end{array}$ & 6.04 & $\begin{array}{l}5.02- \\
7.05\end{array}$ & 60.36 & $\begin{array}{l}50.21- \\
70.51 \\
\end{array}$ & 5.11 & $\begin{array}{l}4.22- \\
5.99 \\
\end{array}$ \\
\hline 11 & 4.63 & $\begin{array}{l}2.06- \\
7.19 \\
\end{array}$ & 6.38 & $\begin{array}{l}3.81- \\
8.94 \\
\end{array}$ & 0.63 & $\begin{array}{c}-0.14- \\
1.40 \\
\end{array}$ & 5.75 & $\begin{array}{l}3.31- \\
8.19 \\
\end{array}$ & 52.27 & $\begin{array}{l}30.12- \\
74.43\end{array}$ & 4.51 & $\begin{array}{c}2.44- \\
6.57 \\
\end{array}$ \\
\hline 12 & 7.25 & $\begin{array}{l}-1.5- \\
16.00\end{array}$ & 4.75 & $\begin{array}{l}-4.0- \\
13.50\end{array}$ & 0.75 & $\begin{array}{c}-1.64- \\
3.14\end{array}$ & 4.00 & $\begin{array}{l}-3.5- \\
11.5\end{array}$ & 33.33 & $\begin{array}{l}-28.86- \\
95.5\end{array}$ & 3.34 & $\begin{array}{c}-2.90- \\
9.58\end{array}$ \\
\hline
\end{tabular}

$\bar{x}$ : mean value, $\mathrm{Cl}$ : 95\% Confidence Interval

of different clutch sizes for which the exact reproductive history was detected, the percentage of non-hatched eggs was higher in the case of smaller and larger clutch sizes while it was lower in the case of more frequent clutch sizes (clutches of 4-9 eggs) in the first annual clutches (Table 1). Another type of percentage distribution of egg losses was obtained from the data of second annual clutches: the higher proportion of non-hatched eggs was detected in case of modal clutch size (7 eggs), in addition, the percentage value of egg losses was typically higher likewise in case of larger clutch sizes (13-14 eggs) (Table 2). Considering the initial clutch sizes, the distribution of unhatched eggs' proportion was not homogeneous in the comparison of the first $(20.72 \%, 1,130$ non-hatched eggs out of 5,454 total eggs) and the second ( $28.75 \%$, 410 non-hatched eggs out of 1,426 total eggs) nesting periods $\left(\chi^{2}=41.53, P<0.001\right)$. As regards the results of all successful nests, the mean of egg losses was higher in the case of larger clutches (9-12 eggs) in the first annual breeding period, however due to an overlap of 95\% confidence interval, egg losses did not differ significantly between clutch sizes (Table 3). Although the mean value of egg losses was higher in larger clutch sizes in the second annual 
Table 4. Variation of the main and $95 \%$ confidence interval of breeding parameters in relation to initial clutch size for clutches where complete reproduction history was known in the second annual breeding period

4. táblázat A költési paraméterek átlag és 95\%-os konfidencia intervallum értékeinek eltérése a kezdeti fészekalj méretek függvényében, melyeknél ismert a teljes reprodukciós történet a másodköltés időszakában

\begin{tabular}{|c|c|c|c|c|c|c|c|c|c|c|c|c|}
\hline \multirow{2}{*}{$\begin{array}{l}\frac{N}{N} \\
\frac{N}{U} \\
\frac{U}{3}\end{array}$} & \multicolumn{2}{|c|}{$\begin{array}{l}\text { Unhatched } \\
\text { eggs }\end{array}$} & \multicolumn{2}{|c|}{$\begin{array}{c}\text { Eggs } \\
\text { hatched }\end{array}$} & \multicolumn{2}{|c|}{$\begin{array}{l}\text { Brood } \\
\text { reduction }\end{array}$} & \multicolumn{2}{|c|}{$\begin{array}{l}\text { Young } \\
\text { fledged }\end{array}$} & \multicolumn{2}{|c|}{$\begin{array}{l}\text { Reproductive } \\
\text { success }\end{array}$} & \multicolumn{2}{|c|}{ Productivity } \\
\hline & $\overline{\boldsymbol{x}}$ & $\mathrm{Cl}$ & $\bar{x}$ & $\mathrm{Cl}$ & $\bar{x}$ & $\mathrm{Cl}$ & $\bar{x}$ & $\mathrm{Cl}$ & $\bar{x}$ & $\mathrm{Cl}$ & $\overline{\boldsymbol{x}}$ & $\mathrm{Cl}$ \\
\hline 2 & 0 & - & 2 & - & 0 & - & 2 & - & 100 & - & 1.61 & $\begin{array}{l}1.20- \\
2.02\end{array}$ \\
\hline 3 & 0.67 & $\begin{array}{l}-0.77- \\
2.10\end{array}$ & 2.33 & $\begin{array}{l}0.90- \\
3.77\end{array}$ & 1 & $\begin{array}{c}-1.48- \\
3.48\end{array}$ & 1.33 & $\begin{array}{l}-0.1- \\
2.77\end{array}$ & 44.44 & $\begin{array}{l}-3.36- \\
92.25\end{array}$ & 0.84 & $\begin{array}{l}-0.29- \\
1.97\end{array}$ \\
\hline 4 & 2 & - & 2 & - & 0.5 & - & 1.5 & - & 37.5 & - & 1.03 & - \\
\hline 5 & 1.48 & $\begin{array}{l}0.58- \\
2.37\end{array}$ & 3.52 & $\begin{array}{l}2.63- \\
4.42 \\
\end{array}$ & 0.86 & $\begin{array}{l}0.40- \\
1.32\end{array}$ & 2.67 & $\begin{array}{l}1.82- \\
3.51\end{array}$ & 53.33 & $\begin{array}{c}36.46- \\
70.2\end{array}$ & 1.97 & $\begin{array}{l}1.33- \\
2.61\end{array}$ \\
\hline 6 & 1.11 & $\begin{array}{l}0.45- \\
1.77\end{array}$ & 4.89 & $\begin{array}{c}4.23- \\
5.56\end{array}$ & 1.05 & $\begin{array}{l}0.53- \\
1.57\end{array}$ & 3.84 & $\begin{array}{l}3.19- \\
4.49\end{array}$ & 64.04 & $\begin{array}{l}53.24- \\
74.83\end{array}$ & 2.89 & $\begin{array}{l}2.41- \\
3.37\end{array}$ \\
\hline 7 & 2.36 & $\begin{array}{l}1.70- \\
3.02\end{array}$ & 4.64 & $\begin{array}{l}3.98- \\
5.30\end{array}$ & 1.55 & $\begin{array}{l}1.02- \\
2.08\end{array}$ & 3.10 & $\begin{array}{c}2.43- \\
3.76\end{array}$ & 44.22 & $\begin{array}{c}34.69- \\
53.74\end{array}$ & 2.41 & $\begin{array}{l}1.87- \\
2.95\end{array}$ \\
\hline 8 & 1.74 & $\begin{array}{l}1.09- \\
2.69\end{array}$ & 6.26 & $\begin{array}{l}5.61- \\
6.92\end{array}$ & 1.29 & $\begin{array}{l}0.79- \\
1.79\end{array}$ & 4.97 & $\begin{array}{c}4.33- \\
5.62\end{array}$ & 62.13 & $\begin{array}{l}54.06- \\
70.20\end{array}$ & 3.81 & $\begin{array}{l}3.17- \\
4.49\end{array}$ \\
\hline 9 & 2.75 & $\begin{array}{l}2.11- \\
3.39\end{array}$ & 6.25 & $\begin{array}{l}5.61- \\
6.89\end{array}$ & 1.29 & $\begin{array}{l}0.74- \\
1.83\end{array}$ & 4.96 & $\begin{array}{l}4.28- \\
5.95\end{array}$ & 55.16 & $\begin{array}{l}47.52- \\
62.80\end{array}$ & 4.14 & $\begin{array}{l}3.46- \\
4.83\end{array}$ \\
\hline 10 & 2.81 & $\begin{array}{l}1.69- \\
3.93\end{array}$ & 7.19 & $\begin{array}{l}6.07- \\
8.31\end{array}$ & 1.44 & $\begin{array}{l}0.74- \\
2.14 \\
\end{array}$ & 5.75 & $\begin{array}{l}4.53- \\
6.97\end{array}$ & 57.5 & $\begin{array}{l}45.27- \\
69.73\end{array}$ & 4.84 & $\begin{array}{l}3.56- \\
6.12\end{array}$ \\
\hline 11 & 3.25 & $\begin{array}{l}2.01- \\
4.50 \\
\end{array}$ & 7.75 & $\begin{array}{l}6.51- \\
8.99 \\
\end{array}$ & 1.33 & $\begin{array}{l}0.55- \\
2.12 \\
\end{array}$ & 6.42 & $\begin{array}{l}5.08- \\
7.76\end{array}$ & 57.33 & $\begin{array}{l}43.15- \\
70.51 \\
\end{array}$ & 5.17 & $\begin{array}{l}4.08- \\
6.26 \\
\end{array}$ \\
\hline 12 & 3.33 & $\begin{array}{l}1.90- \\
4.77\end{array}$ & 8.67 & $\begin{array}{l}7.23- \\
10.10\end{array}$ & 0.33 & $\begin{array}{l}-1.1- \\
1.77 \\
\end{array}$ & 8.33 & $\begin{array}{l}6.90- \\
9.77\end{array}$ & 69.44 & $\begin{array}{l}57.49- \\
81.40\end{array}$ & 7.44 & $\begin{array}{l}2.74- \\
12.15\end{array}$ \\
\hline 13 & 8.00 & - & 5.00 & - & 1.00 & - & 4.00 & - & 30.77 & - & 3.28 & - \\
\hline
\end{tabular}

$\bar{x}$ : mean value, Cl: 95\% Confidence Interval

clutches, the average number of unhatched eggs was more balanced than in the first breeding periods. Due to the overlap between $95 \%$ confidence intervals of means we did not find significant difference in the comparison of different clutch sizes (Table 4).

The mean brood size per nest of the first annual clutches was $5.42 \pm 0.07,5.44 \pm 0.07$ for second clutches, and $5.43 \pm 0.07$ for the total annual breeding periods. The number of nestlings did not differ between the first and second annual clutches (Mann-Whitney U-test: $Z=0.9, P=0.771)$. In contrast, the mean of hatching success per nest was higher in the first $(79.81 \pm 0.93 \%)$ than in the second clutches $(71.86 \pm 1.98 \%)$ (Mann-Whitney U-test: $Z=4.9, P<0.001)$. The average value of hatching success was $78.31 \pm 0.85 \%$ for the whole annual breeding periods.

Brood sizes at hatching of $6(25.72 \%), 5(19.95 \%)$ and $7(18.57 \%)$ nestlings were observed most frequently in the first annual clutches, the cumulative proportion of these three 
brood sizes being $64.24 \%$ of all clutches. In the case of the second annual clutches, the modal brood size was 5 nestlings which was detected with the highest frequency $(23.24 \%)$ and the relative frequency of brood size of $7(16.76 \%)$ and $6(15.14 \%)$ nestlings was even higher. Therefore, the cumulative percentage of these three brood sizes was $55.14 \%$ of all clutches. In addition, in the case of total annual breeding seasons the brood size of $6(23.73 \%)$, $5(20.57 \%)$ and $7(18.23 \%)$ nestlings were detected with higher frequency, the cumulative percentage of these three brood sizes adding up to $62.53 \%$ of the total clutches (Figure 2).

Regarding brood size and hatching success in relation to initial clutch size, the cumulative number of hatchlings was the highest in the case of modal clutch size (7 eggs) in the first annual clutches and the clutch size of 8 eggs in the second clutches (Table 1-2). In contrast, the percentage distribution of hatching success in the first annual clutches was similarly high in the case of more clutch sizes (4-9 eggs), while higher proportion of hatching success was observed not only for the most frequent clutch sizes but also for smaller and larger ones in the second nesting period (Table 1-2). Considering different clutch sizes, the mean of brood size was higher in the case of larger clutch sizes (7-10 eggs) in the first annual breeding period, which average values were significantly higher than the mean of smaller clutch sizes (2-6 eggs), due to the lack of overlapping confidence intervals (Table 3 ). The mean of nestlings was similarly higher in larger clutch sizes in the second annual breeding season, due to the separation of confidence intervals; the average values of clutch size of 8-12 eggs were significantly higher than in the case of smaller clutch sizes (5-7 eggs) (Table 4).

\section{Brood reduction, young fledged and fledging success}

In the case of first annual clutches, the average number of brood reduction per nest was $0.93 \pm$ $0.05,1.24 \pm 0.101$ for the second clutches and $0.98 \pm 0.04$ for the whole annual breeding periods. Brood reduction was higher in the second than the first annual clutches (Mann-Whitney U-test: $Z=3.41, P<0.001)$. Considering the initial clutch sizes, the loss of nestlings was the highest in the case of modal clutch size (7 eggs), but the proportion of brood reduction was also higher in the case of larger (8-9 eggs) and smaller (3-4 eggs) clutch sizes in the first breeding season (Table 1). Similarly, brood reduction was the highest in the case of modal clutch size (7 eggs) in the second annual clutches, but the largest percentage value of brood reduction was typical only for this clutch size (Table 2). The distribution of brood reduction was not homogeneous in the comparison of first (17.14\%, 741 out of 4,324 total hatchlings) and second annual breeding periods $\left(22.64 \%, 230\right.$ out of 1,016 total hatchlings) $\left(\chi^{2}=16.37, P<0.001\right)$, the degree of hatchling losses being higher in the second than the first annual clutches. Comparing egg and hatchling losses, the loss of eggs was larger in both the first $\left(\chi^{2}=19.77, P<\right.$ $0.001)$ and the second $\left(\chi^{2}=11.15, P<0.001\right)$ annual clutches. Based on data of all successful nests, the mean of brood reduction per different clutch sizes ranged from 0.43 to 1.34 in the first annual clutches, the degree of brood reduction did not differ significantly in the comparison of clutch sizes (Table 3). The average number of hatchling losses per different clutch sizes varied between 0.5 and 1.55 in the second annual breeding period, however due to overlap of the $95 \%$ confidence intervals considering the loss of hatchlings we did not find significant difference between clutch sizes (Table 4). 
The mean of young fledged per nest varied between 0 and $9(4.45 \pm 0.07)$ in the total annual breeding season while it varied in the same range in the first $(4.49 \pm 0.07)$ and in the second $(4.25 \pm 0.17)$ annual clutches. There was no significant difference in the amount of fledglings between the first and second annual breeding season (Mann-Whitney U-test: $Z=$ $1.71, P=0.088)$, while fledging success was greater in the first $(77.91 \pm 1.09 \%)$ than in the second $(71.47 \pm 2.3 \%$ ) annual clutches (Mann-Whitney U-test: $Z=3.41, P<0.001$ ).

The distribution of fledglings showed that 4-6 fledged young birds were observed most frequently in the first annual clutches, so the cumulative proportion of these three brood sizes at fledgling was $60.1 \%$ of all clutches. In the case of the second annual breeding seasons, 3-6 fledglings were produced by Common Barn-owls most frequently, the cumulative proportion of these four brood sizes at fledging being $61.63 \%$ of all breeding pairs. As regards the whole breeding periods, 4-6 fledged young birds were observed most frequently, the cumulative percentage of these three brood sizes at fledging adding up to $57.43 \%$ of total clutches (Figure 3).

Regarding brood size at fledging in relation to initial clutch size, the cumulative number of fledglings was the highest in the case of modal clutch size (7 eggs) in the first annual clutches and the clutch size of 8 eggs in the second clutches (Table 1-2). However, the percentage value of fledging success was higher in the clutch size of 5 eggs and other larger clutch sizes (10-13 eggs) in the first breeding period while in the case of the second breeding season, higher degrees of fledging success were detected in larger clutch sizes (8-14 eggs), except for the clutch size of 2 eggs (Table 1-2).

\section{Reproductive success and clutch size productivity}

The mean of percentage value of reproductive success per nest of first annual clutches was $66.12 \pm 1.05 \%, 55.09 \pm 1.99 \%$ for second clutches and $64.04 \pm 0.94 \%$ for the whole annual breeding periods. There was significant difference in reproductive success between the first and second annual clutches (Mann-Whitney U-test: $Z=5.63, P<0.001$ ). Considering initial clutch size, the average value of reproductive success was higher in the case of clutch sizes of 5-9 eggs, however, due to the $95 \%$ overlapping confidence intervals, it did not significantly differ in the comparison of clutch sizes in the first annual breeding season (Table 3). The mean of reproductive success was the highest in case of clutch size of 12 eggs in the second annual breeding period, but the lack of non-overlapping confidence intervals we did not find significant difference between clutches (Table 4). As regards initial clutch size, calculated productivity rate was not the highest from the pooled data in the case of modal clutch size; productivity showed an increasing trend relative to clutch sizes which was typical in both breeding periods (Table 1-2). According to the results of all successful clutches, the mean of productivity was higher in case of larger clutch sizes (6-11 eggs) thus, the rate of young produced was significantly lower in the clutch size of 3-5 eggs than in case of other larger clutch sizes (6-11 eggs) in the first annual breeding season (Table 3). The calculated productivity value from the second annual clutches similarly increased depending on clutch size, the rate of productivity being significantly lower in clutch sizes of 3-5 eggs than in larger clutch sizes (6-10 eggs), except for the clutch sizes 11 and 12 eggs due to the overlapping of confidence intervals (Table 4). 


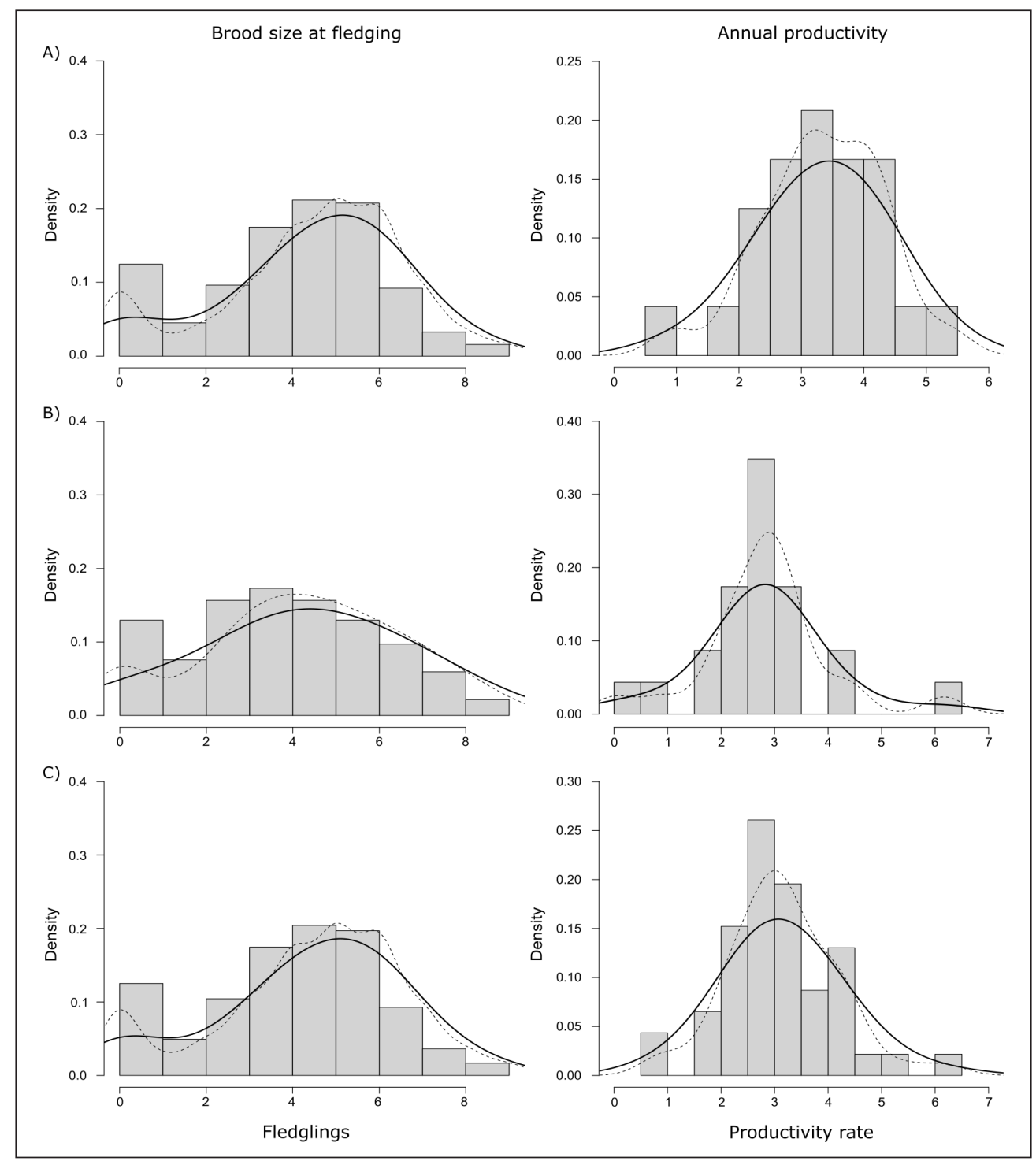

Figure 3. Histograms and smoothed histograms with first (dashed line) and second (solid line) order smoother of fledgling numbers and annual productivity distribution in the first $(A)$ and second (B) annual clutches as well as in whole breeding season (C)

3. ábra A kirepült fiókaszám és az éves produktivitás eloszlásának hisztogramja és simított hisztogramja első- (szaggatott vonal) és másodrendű (folytonos vonal) simítással az első ( $A$ ) és másodköltés (B), valamint a teljes szaporodási időszakban (C)

Considering all successful clutches we found significant positive linear regression between clutch size and productivity rate in both the first $\left(R^{2}=0.15, F=142.1, P<0.001\right.$; $\left.B_{\text {slope }}=0.45, t=11.92, P<0.001\right)$ and the second $\left(R^{2}=0.27, F=66.39, P<0.001 ; B_{\text {slope }}=\right.$ $0.52, t=8.15, P<0.001$ ) breeding season (Figure 4). 


\section{Annual patterns of breeding parameters and productivity}

The average number of eggs laid per year of first annual clutches was $227.25 \pm 26.31$ (range $29-518$ ), $64.82 \pm 12.36$ (range $6-206$ ) for second clutches and $149.56 \pm 19.11$ (range 6 - 518) for the whole annual breeding seasons. The number of eggs per year was significantly different between the two annual breeding periods (Mann-Whitney U-test: $Z=4.76$, $P<0.001)$. Based on data of complete annual breeding cycles, the variation of clutch size showed fluctuation during the years (Kruskal-Wallis test: $H(23, N=982)=144.52, P<$ 0.001 ) which was detected at its largest average clutch size value in 2014. It was significantly higher than the clutch size obtained in the other years, except for 1995 (post hoc Dunn test: $z=4.02-9.01, P<0.05$ ) (Figure 5A).

The average proportion of egg loss per year for first clutches was $21.65 \pm 1.74 \%$ (range $10.17-48.74 \%$ ), $25.45 \pm 2.88 \%$ (range $0-50 \%$ ) for second clutches and $23.47 \pm 1.66 \%$ (range $0-50 \%$ ) for the whole annual breeding periods. Although the higher proportion of non-hatched eggs was observed in the second annual clutches, egg losses did not differ significantly between the two annual breeding seasons (Mann-Whitney U-test: $Z=0.78, P=$ 0.431). Considering the whole annual breeding periods, the percentage value of egg loss varied among the years (Kruskal-Wallis test: $H(23, N=982)=47.59, P<0.01$ ), the highest proportion of non-hatched eggs being detected in 2010 (Figure 5B). During the 24 years, the rate of egg loss showed decline with significant negative linear trend $\left(R^{2}=0.099, F=4.85\right.$, $P<0.05 ; B_{\text {slope }}=-0.51, t=2.25, P<0.05$ ) (Figure 6A).

As regards the brood size at hatching, the average number of hatchlings per year of first annual clutches was $180.17 \pm 21.91$ (range $26-419$ ), $46.18 \pm 8.88$ (range $6-146$ ) for the second clutches and $116.08 \pm 15.66$ (range $6-419$ ) for the whole annual breeding periods.

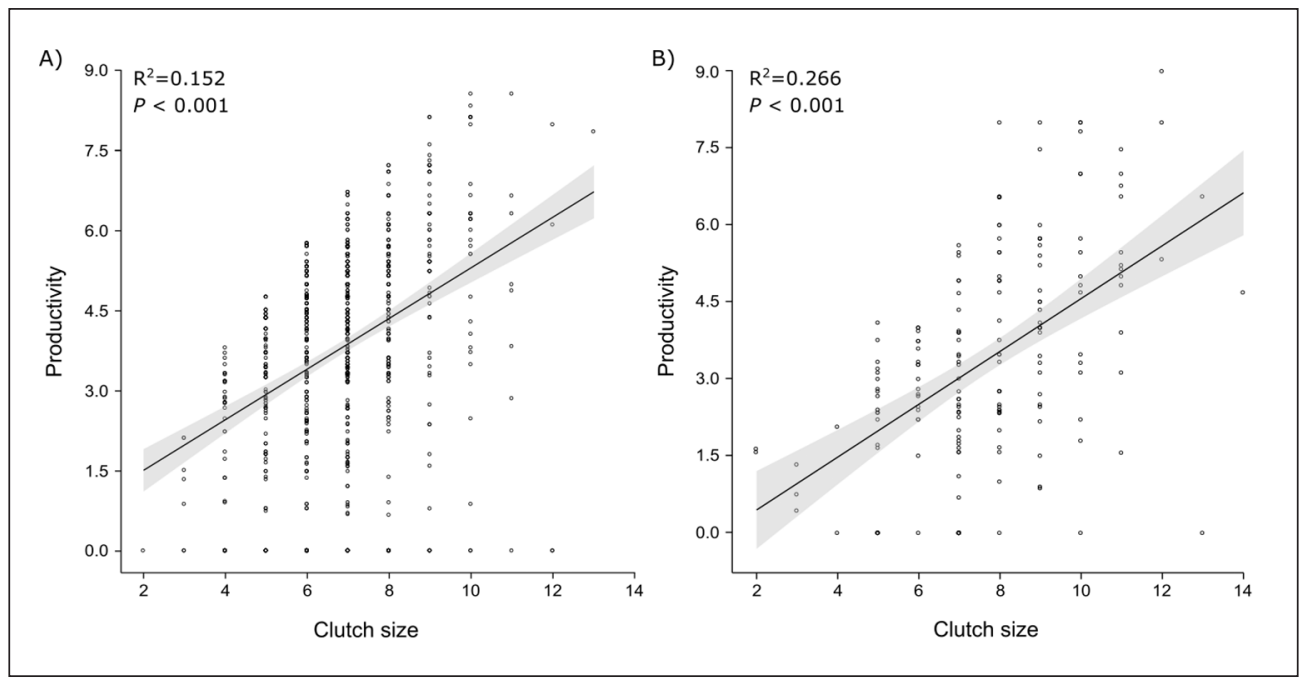

Figure 4. Relationship between clutch size and productivity (fledglings per nesting attempt) in the first (A) and second (B) annual clutches

4. ábra Afészekaljméretés produktivitás (kirepült fiókák/megkezdettfészkelések száma) összefüggése az első (A) és a másodköltés (B) időszakában 


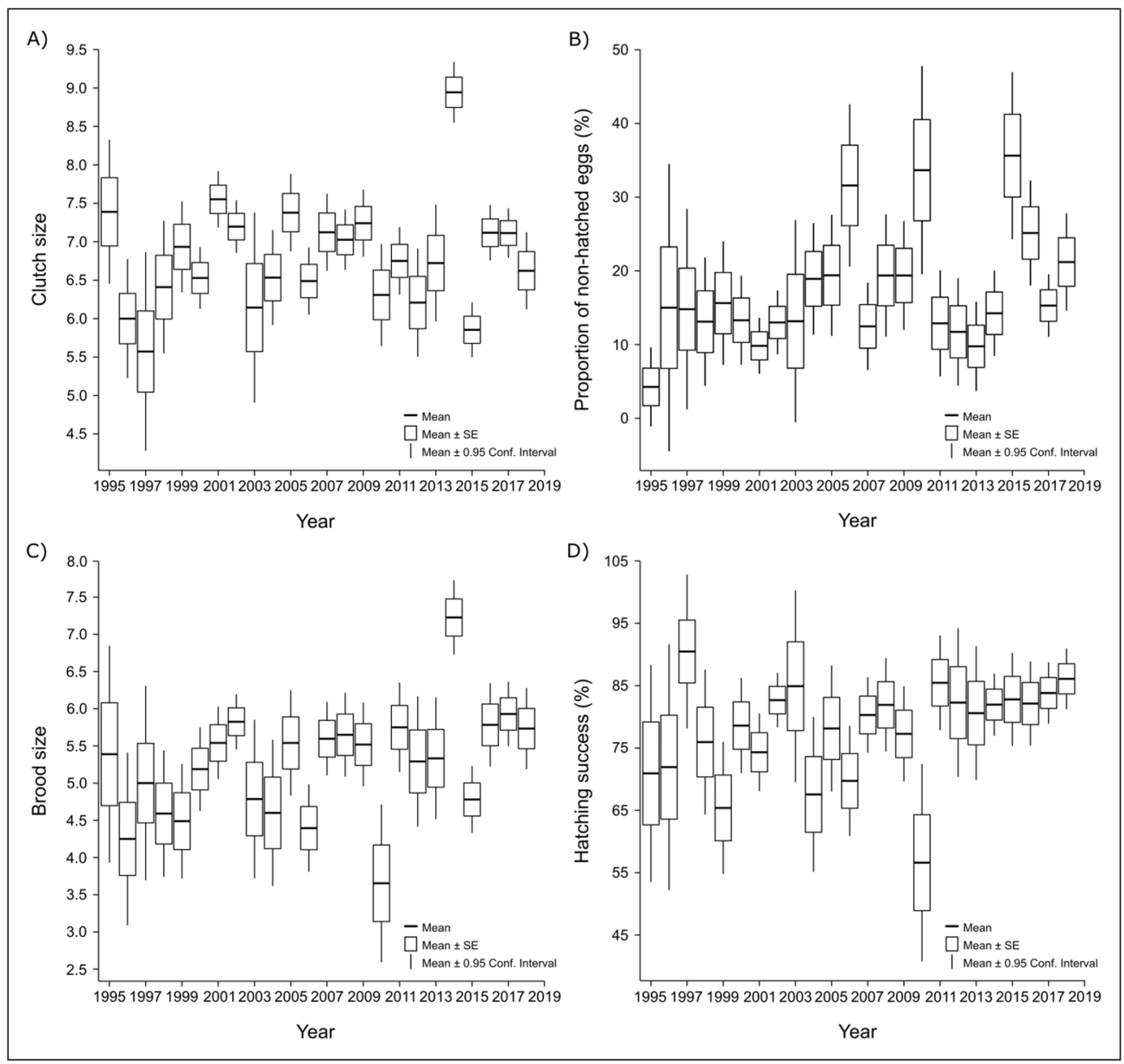

Figure 5. Fluctuation of the annual values (mean $\pm \mathrm{SE}, 95 \% \mathrm{Cl}$ ) of clutch size (A), proportion of egg loss (B), brood size (C) and hatching success (D) during the 24 years

5. ábra A fészekalj méret (A), a tojás veszteség arányának (B), a kikelt fiókák számának (C) és a kelési siker (D) éves értékének (átlag \pm standard hiba, 95\%-as konfidencia intervallum) fluktuációja a 24 év során

A significant difference in hatchling numbers was observed in the comparison of first and second clutches (Mann-Whitney U-test: $Z=4.76, P<0.001$ ). Considering the total breeding periods, brood size varied similarly to the amount of eggs laid during the monitoring period and it was significantly different among years (Kruskal-Wallis test: $H(23, N=982)=114.11, P<$ 0.001). The maximum average value of nestlings was detected in 2014 similarly to egg productivity but a significantly lower average value of brood size was observed in 2010 compared to several years $(2002,2014,2016,2017)$ (post hoc test: $z=3.79-6.53, P<0.05$ ) (Figure 5C).

Taking into account the above, the mean of hatching success per year of the first annual clutches was $78.35 \pm 1.74 \%$ (range $51.26-89.83$ ), $74.08 \% \pm 2.81 \%$ (range $50-100$ ) for second clutches and $76.31 \% \pm 1.63 \%$ (range $50-100$ ) for the whole annual breeding seasons. 
Significant difference was not observed between two annual breeding periods (Mann-Whitney U-test: $\mathrm{Z}=1.53, P=0.125$ ). Considering the whole breeding seasons, despite that the degree of hatching success was less fluctuating during the monitoring period, it differed significantly among years (Kruskal-Wallis test: $\mathrm{H}(23, N=982)=47.59, P<0.01)$. The lowest average rate of hatching success was detected in 2010 (Figure 5D). Despite this minimum value, hatching success increased with significant positive linear trend $\left(\mathrm{R}^{2}=0.091, \mathrm{~F}=4.42\right.$, $P<0.05 ; \mathrm{B}_{\text {slope }}=0.48, \mathrm{t}=2.10, P<0.05$ ) during the 24 years (Figure $6 B$ ).

The average proportion of brood reduction per year of the first annual clutches was $18.35 \pm$ $2.08 \%$ (range $3.61-50.82 \%$ ), $24.29 \% \pm 2.89 \%$ (range $0-51.72 \%$ ) for second clutches and $21.19 \% \pm 1.79 \%(N=46$, range $0-51.72 \%)$ for the whole annual breeding period. Although the loss of hatchlings was higher in the second annual clutches, significant difference was not found between the two annual breeding seasons (Mann-Whitney $\mathrm{U}$-test: $\mathrm{Z}=1.35, P=0.176$ ). The percentage value of this parameter from the total annual clutches varied significantly among the years (Kruskal-Wallis test: $\mathrm{H}(23, N=982)=69.32, P<0.001)$. Higher average proportions of brood reduction were observed in three years $(2007,2010,2015)$ while the degree of nestling loss was the lowest in 1995 (post hoc test: $\mathrm{z}=3.76-4.19, P<0.05$ ) (Figure 7 A).

Considering brood sizes at fledging, the average number of fledglings per year was 149.29 \pm 19.38 (range $21-364$ ), $35.5 \pm 7.54$ (range $6-125$ ) for the second clutches and $94.87 \pm$ 13.59 (range 6 - 364) for the whole annual breeding periods. The quantity of fledglings was significantly higher in the first than in the second annual clutches (Mann-Whitney U-test: Z $=4.78, P<0.001)$. As regards the total breeding seasons, the amount of fledglings significantly differed among the years (Kruskal-Wallis test: $\mathrm{H}(23, N=982)=145.46, P<0.001)$. The greatest number of fledglings was observed in 2014 which was significantly higher compared to other years (post hoc test: $\mathrm{z}=3.83-7.61, P<0.05$ ). Due to the higher degree of brood reduction, the significantly smaller number of fledglings was also typical in 2010 (post hoc test: $\mathrm{z}=3.75-7.61, P<0.05$ ) (Figure $7 B$ ).

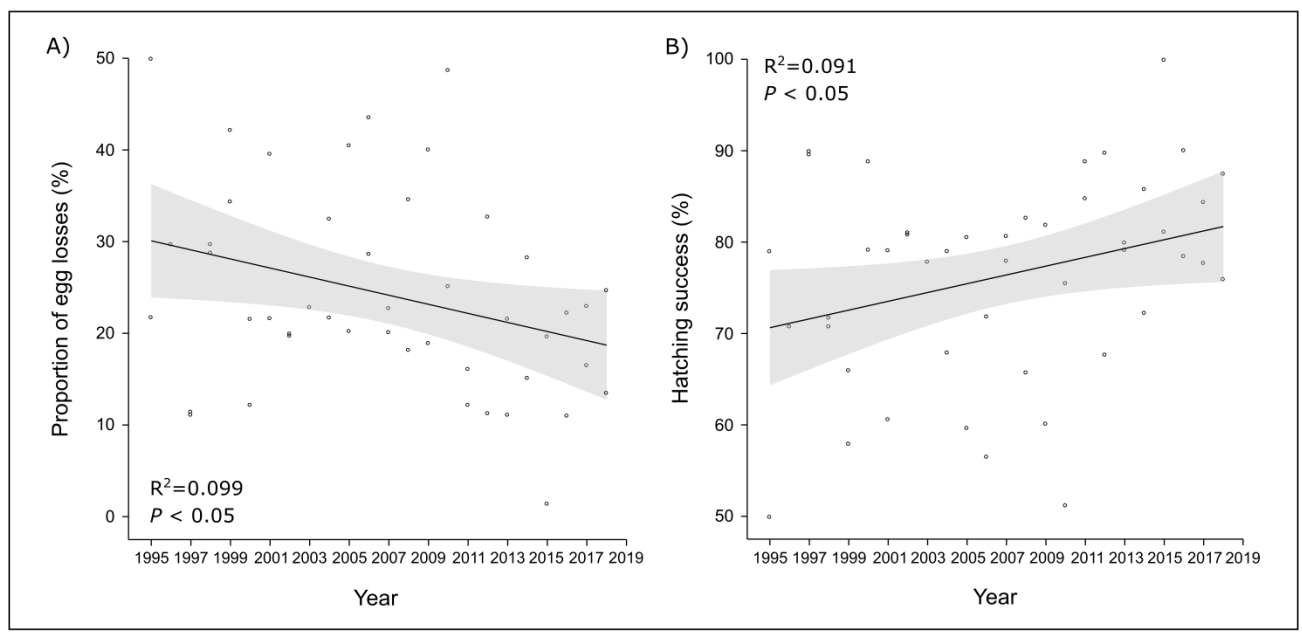

Figure 6. Temporal change of the proportion of egg loss (A) and hatching success (B) during the monitoring period

6. ábra A tojás veszteség (A) és a kelési siker (B) időbeli változása a monitorozási periódus alatt 


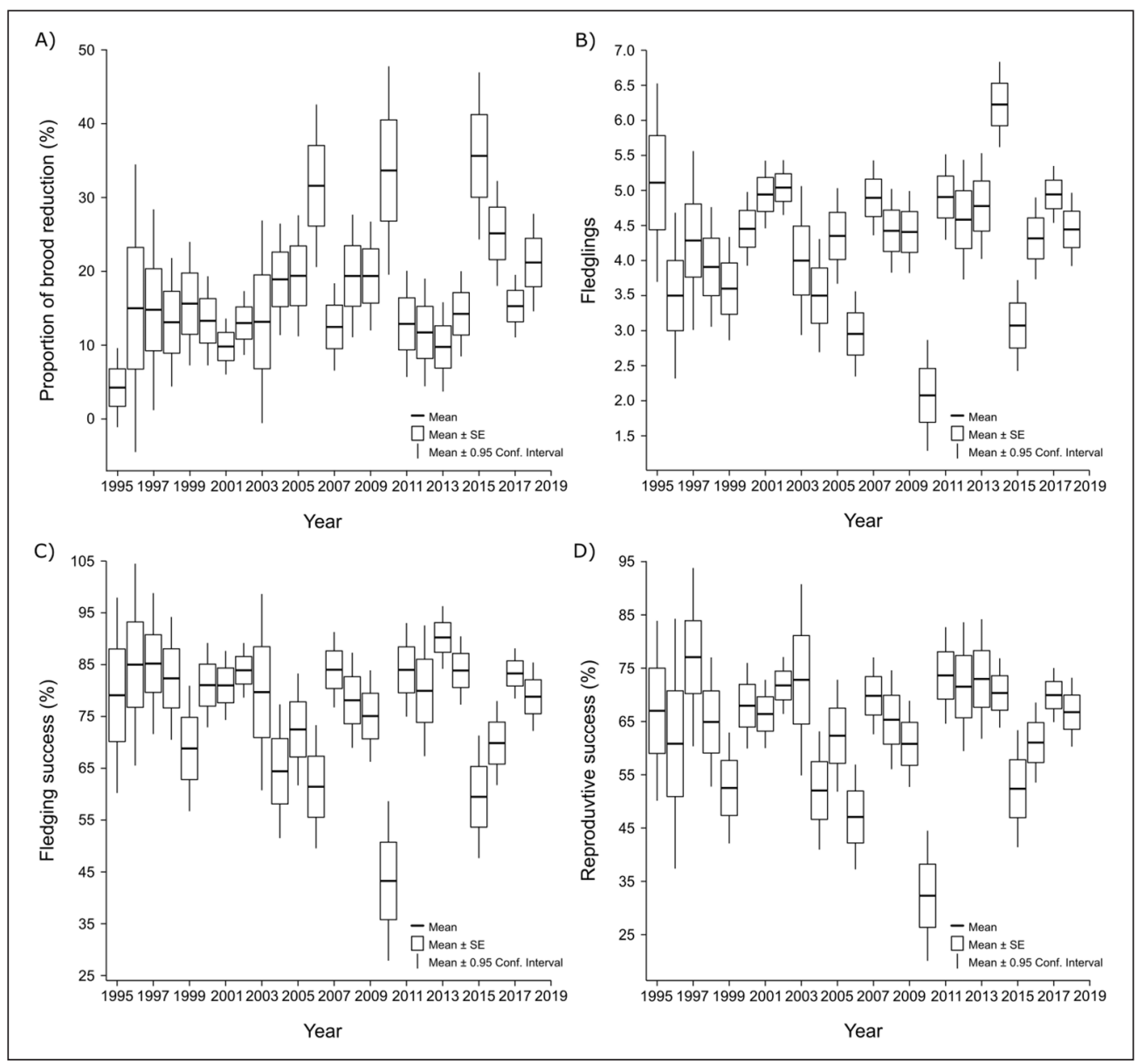

Figure 7. Fluctuation of the annual values (mean $\pm \mathrm{SE}, 95 \% \mathrm{Cl}$ ) of brood reduction $(\mathrm{A})$, fledglings $(\mathrm{B})$, fledging success $(C)$ and reproductive success $(D)$ during the 24 years

7. ábra A kikelt fiókák vesztesége (A), a kirepült fiókák számának (B), a kirepülési (C) és a szaporodási siker (D) éves értékének (átlag \pm standard hiba, 95\%-as konfidencia intervallum) fluktuációja a 24 év során

The mean of fledging success per year varied within the same range $(48.27-100 \%)$ in the first $(81.65 \% \pm 2.08 \%)$, second $(75.70 \% \pm 2.89 \%)$ clutches and in the whole annual breeding seasons $(78.81 \% \pm 1.79 \%)$. As regards the whole annual breeding seasons, the fledging success significantly differed between years (Kruskal-Wallis test: $\mathrm{H}(23, N=982)=79.97$, $P<0.001)$. Due to the high degree of brood reduction, these results of median test were determined essentially by the lowest rate of fledging success in 2010, which differed significantly in the comparison of several years (post hoc: $\mathrm{z}=3.75-7.61, P<0.05$ ) (Figure $7 C$ ).

The rate of reproductive success per year ranged from 25.21 to $79.66 \%(64.39 \pm 2.38 \%)$ in the first, from 28 to $100 \%(56.40 \% \pm 3.46 \%)$ in the second clutches and from 25.21 to $100 \%(60.57 \pm 2.13 \%)$ in the total annual breeding seasons. Considering the whole breeding periods, reproductive success showed similar annual fluctuation to fledging success, which 


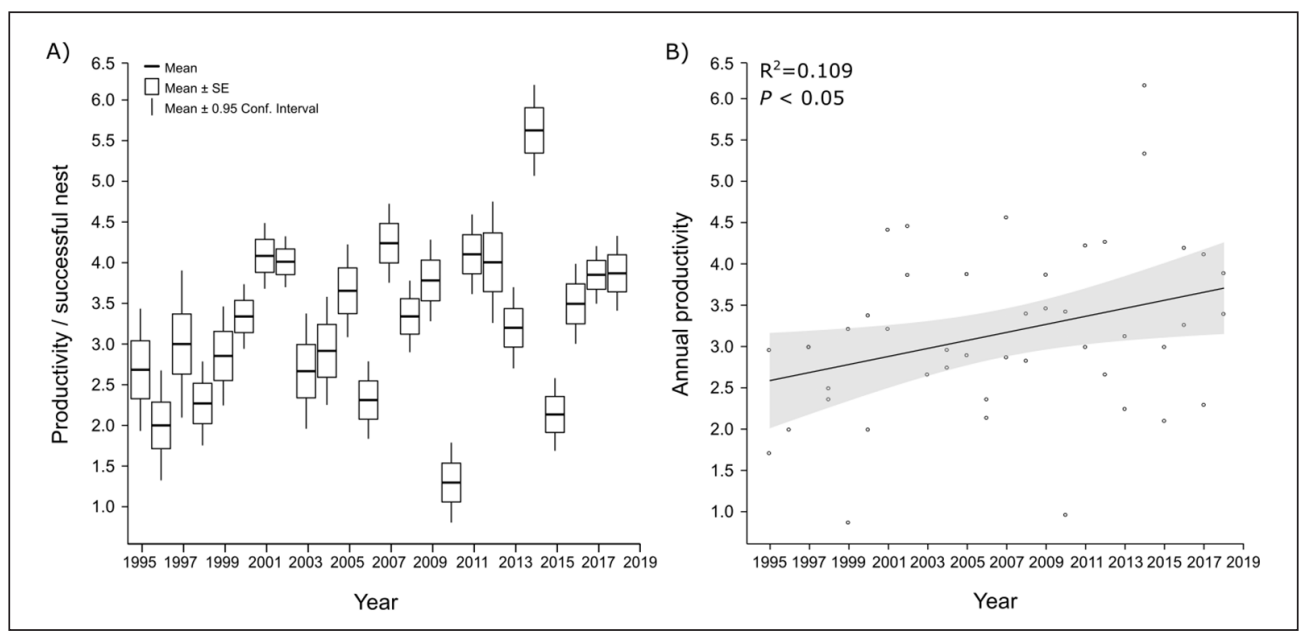

Figure 8. Fluctuation of the annual values (mean $\pm \mathrm{SE}, 95 \% \mathrm{Cl}$ ) of productivity per successful nest $(\mathrm{A}$ ) and the changes of annual productivity of Common Barn-owls (B) during the 24-year monitoring period

8. ábra A sikeres fészkek produktivitás értékének (átlag \pm standard hiba, 95\%-as konfidencia intervallum) fluktuációja (A) és a gyöngybaglyok éves produktivitásának változása (B) a 24 éves monitoring során

differed among the years (Kruskal-Wallis test: $\mathrm{H}(23, N=982)=81.53, P<0.001)$ because a significant yearly decline in reproductive success was observed in 2010 in comparison to several years (post hoc test: $\mathrm{z}=3.75-4.99, P<0.05$ ) (Figure $7 D$ ).

Based on the number of fledglings of successful nests, the mean of annual productivity fluctuated between 0.97 and $5.34(3.44 \pm 0.19)$ in the first, 0.87 and $6.17(2.96 \pm 0.23)$ in the second annual clutches, and between 0.87 and $6.17(3.16 \pm 0.15)$ in the total annual breeding seasons. We did not find significant difference of productivity between the first and second annual clutches (Mann-Whitney U-test: $\mathrm{Z}=1.85, P=0.064$ ). Based on the distribution of annual productivity rate, $2.8-4.5$ fledglings per nesting attempt were observed most frequently in the first breeding seasons, so this range of productivity was typical in 17 cases out of total sample (72\%) (Figure 3).

In case of second clutches, 8 fledglings per nesting attempt were observed most frequently $(36 \%, 8$ out of 22 case numbers) while productivity of $2.5-3.5$ fledglings per nesting attempt was calculated most frequently $(46 \%, 21$ out of 46 samples) in the whole annual breeding periods (Figure 3). The annual productivity of Common Barn-owls differed significantly among the years (Kruskal-Wallis test: $\mathrm{H}(23, N=982)=223.94, P<0.001)$. The greatest productivity rate was observed in 2014 which was significantly higher compared to other years (post hoc test: $\mathrm{z}=4.20-9.23, P<0.01$ ). Due to lower fledgling production, the significant low productivity was typical in 2010 (post hoc test: $\mathrm{z}=4.42-9.23, P<0.01$ ) (Figure $8 A$ ). Considering the complete annual breeding cycles, the annual variation of productivity showed significant slightly positive linear trend $\left(\mathrm{R}^{2}=0.109, \mathrm{~F}=5.38, P<0.05\right.$; $\left.\mathrm{B}_{\text {slope }}=0.048, \mathrm{t}=2.32, P<0.05\right)$ during the 24 years (Figure $8 B$ ). 


\section{Discussion}

In this study, we evaluated the results of a long-term Common Barn-owl nest box installation programme in Southern Hungary. The number of placed nest boxes varied from 43 to 163 during the 24-year-long monitoring period, and the average percentage of nest box occupancy per year was $34.22 \pm 3.37 \%$ (yearly range $9.72-73.44 \%$ ) at the start of first annual clutches which was lower than that reported in other studies. In the USA (northern Utah) $50 \%$ of installed nest boxes were occupied in the first and $80 \%$ of boxes were used in the second year, which was observed when a low number of boxes were placed ( $N$ = 30) (Marti et al. 1979) and the average percentage of occupied nest boxes was $81.35 \pm$ $6.32 \%$ (yearly range $53.3-96.7 \%$ ) during the 6 years (Marti \& Wagner 1985). Also during the 6 years, 41 nest boxes were installed in a similar program in the USA, however, the rate of nest box occupancy per year was $65.29 \pm 6.41 \%$ (Looman et al. 1996). In a long-term study (13 breeding seasons), $51.7 \pm 3.7 \%$ (yearly range $=25.7-73.5 \%$ ) of all placed nest boxes $(N=309)$ per year were occupied by Common Barn-owl pairs in the Middle-East (Beit She'an Valley, Israel) (Charter et al. 2017). The first five-year evaluation of this monitoring program is also worth highlighting, when the mean percentage of nest boxes $(N=248)$ occupied was $53.5 \pm 2.1 \%$ (Meyrom et al. 2009). Although the yearly range of nest box occupancy rate was greater according to our results than the occupancy range defined in the Middle East (Charter et al. 2017), but the maximum percentage value of occupied nest boxes was very similar in the comparison of the two long-term studies. The lower average proportion of nest box occupancy showed by our results presumably can be traced back to two basic reasons. First, some natural nesting and roosting sites (open church towers, farm buildings and lofts) are still available for the Common Barnowl in the monitored county which is characterized with a multitude of small villages (Bank 1990). Second, the size of the potential regional population of Common Barn-owl showed several collapses due to the impact of extreme periods during the 24 years, which was indicated by the lowest percentage values of nest box occupancy in $1997(9.72 \%)$, $2003(16.28 \%), 2012(14.57 \%)$ and $2013(14.47 \%)$, so these low proportion values influenced the calculated average. Based on the reported nest box occupancy data of Common Barn-owl from Cyprus, the yearly average proportion of occupied nest box was lower $(18.58 \pm 2.98 \%)$ compared to our results (Kassinis \& Roulin 2017). Furthermore, a low nest box occupancy rate was also found in the semiarid pampas of Argentina where the Common Barn-owl occupied the nest boxes only occasionally, which was a consequence of the fact that the applied nest boxes were smaller than in other studies focusing specifically on the Common Barn-owl (Liébana et al. 2013).

The mean proportion of double brood pairs ranged from 0 to $41.46 \%$ in the second annual clutches. This average percentage was higher than that reported by Martínez and Lopez (1999) in the Mediterranean region, where the number of pairs laying a second clutch was $33.3 \%$. The second clutches are frequent in the case of the Common Barn-owl (Roulin et al. 1999), which is an adaptive strategy because regarding the whole breeding season the reproductive success of double brooding pairs is higher than of single-brooded owls (Béziers \& Roulin 2016). 
Although the proportion of occupied nest boxes was lower in the investigated region, nesting success showed higher percentage value in the whole annual breeding season $(83.39 \%)$, indicating the role of the artificial nest boxes in promoting the Common Barn-owl's nesting efficiency (Marti et al. 1979, de Bruijn 1994, Marti 1994, Petty et al. 1994, Taylor 1994, Frey et al. 2011, Charter et al. 2017), similarly to nest box installation programs implemented in other countries. For example, 71\% (Marti 1994) and 85.85\% (Looman et al. 1996) of nesting attempts was successful in the USA, the yearly range of $73.2-93.5 \%$ nesting success was detected in the Middle-East (Charter et al. 2017), and $87.24 \%$ of nesting attempts was successful in western Switzerland based on a 23-year dataset of nest boxes (Frey et al. 2011).

According to our results, the average clutch size of first clutch per nest $(6.84 \pm 0.05, N$ $=797)$ was higher than that reported in other countries of Europe such as Netherlands $(\bar{x}=$ 4.0) (Braaksma \& de Bruijn 1976), England $(\bar{x}=4.68)$ (Bunn et al. 1982), Scotland $(\bar{x}=4.6$, $N=425)$ (Taylor 1994), France (Burgundy) $(\bar{x}=5.89, N=765)$, Czech Republic $(\bar{x}=5.85$, $N=193)$ (Poprach 1996), Spain (Valencia) $(\bar{x}=4.63, N=30)$ (Martínez \& Lopez 1999) and Switzerland $(\bar{x}=5.85, N=193$ ) (Frey et al. 2011). Furthermore, smaller average clutch size was found in other parts of the world such as Mali $(\bar{x}=6.05, N=140)$ (Wilson et al. 1986), Pakistan $(\bar{x}=5.83, N=28$ ) (Mahmood-Ul-Hassan et al. 2007), Utah $(\bar{x}=5.8, N=28)$ (Looman et al. 1996), and even smaller clutch size $(\bar{x}=3.8, N=17)$ was reported from Arkansas (Radley \& Bednarz 2005). Nevertheless, in the first annual breeding period similarly high average clutch size has already been observed in peninsular Malaysia $(\bar{x}=6.6, N=$ 36) (Lenton 1984), northern Utah $(\bar{x}=7.17, N=275)$ (Marti 1994) and British Columbia $(\bar{x}$ $=6.5, N=23$ ) (Andrusiak \& Cheng 1997). Considering the geographical variation of clutch size, our results confirmed that the first clutch size was larger in Hungary than in Spain, contributing to the earlier observation that the clutch size of Common Barn-owl increase from Spain to Hungary in mainland Europe (Roulin 2002a). We found that size of the second annual clutches of Common Barn-owl was significantly larger than the size of first clutches which is in accordance with the results of other studies (Schönfeld \& Gibrig 1975, Kaus 1977, Poprach 1996, Frey et al. 2011). Conversely, the mean of clutch size was significantly larger in the first than the second annual clutches in northern Utah (Marti 1994), Scotland (Taylor 1994) and in Spain, but in the latter case the difference of clutch size was not significant between the two breeding seasons (Martínez \& Lopez 1999). As regards the variation of Common Barn-owl clutch size, the studies showed that the size of second clutches are larger than the first in case of Tyto alba guttata subspecies while that difference is reversed in Tyto alba alba population (Roulin 2002a). Modal clutch size was larger (7 eggs) in our study area than that reported by some other studies since it was 5 eggs in Spain (Martínez \& Lopez 1999), 6 eggs in Mali (Wilson et al. 1986) and in western Switzerland (Chausson et al. 2014a). However, clutches of 7 eggs were detected with the highest frequency in USA (Looman et al. 1996) and Cyprus (Kassinis \& Roulin 2017) which is consistent with our results.

During the 24 years of our study, the average values of unhatched eggs per nest was 1.42 \pm 0.07 in the first annual breeding period, and egg losses were significantly higher in the second than in the first clutches. Mean of disappeared eggs was higher $(\bar{x}=1.7)$ in northern 
Utah (USA) (Marti 1994) and smaller in Switzerland $(\bar{x}=0.42)$ (Chausson et al. 2014a). Considering the initial clutch sizes, we found that the percentage of unhatched eggs was higher in the case of smaller and larger clutch sizes, while it was lower in the case of clutch sizes with high frequency in the first annual breeding period. In contrast, a larger proportion of egg losses was typical in the case of modal and larger clutch size in the second clutches. In addition, the higher degree of egg losses in the second clutches was also confirmed by the inhomogeneous distribution of the pooled quantity of unhatched eggs between the two breeding periods. Contrarily to the present study, unhatched eggs were found only in clutches with 4 or more eggs in Spain (Martínez \& Lopez 1999). However, our results are consistent with this earlier study in that egg losses were higher in the case of larger clutch size which was mainly typical of the second breeding season in our study area.

Mean brood size per nest was higher $(\bar{x}=5.42 \pm 0.07)$ in the first clutches than that detected in other European countries such as Scotland $(\bar{x}=3.4)$ (Taylor 1994), Czech Republic $(\bar{x}$ $=3.82)($ Poprach 1996), Spain $(\bar{x}=3.32)$ (Martínez \& Lopez 1999) and Slovakia $(\bar{x}=4.5)$ (Sárossy 2000). This difference also exists in comparison with previous studies since average brood size ranged from 2.4 to 4.3 in Germany (Schönfeld \& Gibrig 1975) and from 3.0 to 5.1 in eastern France (Müller 1990). Compared to our results, the mean number of nestlings was also smaller in other continents, such as in Mali $(\bar{x}=4.79)$ (Wilson et al. 1986), in Pakistan $(\bar{x}=4.15)$ (Mahmood-Ul-Hassan et al. 2007), in Malaysia $(\bar{x}=4.6)$ (Lenton 1984) and in different parts of North America such as north central Utah: $\bar{x}=3.97$ (Looman et al. 1996), British Columbia: $\bar{x}=3.3$ (Andrusiak \& Cheng 1997) and Florida: $\bar{x}=2.87$ (David 1996). However, a higher average number of nestlings was detected in northern Utah (Marti 1994), thus as regards the brood size at hatching of the Common Barn-owl, our result is consistent with this study. We found that brood size was not significantly different between the first and second annual clutches and it is in accordance with the result which was reported by Marti et al. (1994). In contrast, the average number of nestlings was significantly larger in the first than in the second breeding period in Switzerland (Frey et al. 2011). According to our results, the mean of hatching success per nest was significantly higher in the first (79.81\%) than in the second clutches (71.86\%), but these values were lower than it had been reported from the Mediterranean area (Spain) (83\%) (Martínez \& Lopez 1999).

Several studies pointed out that brood reduction takes place in the first 3 weeks after hatching for various reasons. Nestling losses frequently occur by starvation due to the reduction of food availability, but siblicide and more frequent cannibalism also reduce brood size (Roulin, 2002b). We found that the average number of brood reduction per nest was significantly higher in the second $(\bar{x}=1.24)$ than in first $(\bar{x}=0.93)$ clutches. Based on the cumulative number of disappeared nestlings, the proportion of brood reduction was not homogeneous in comparison of the first (17.14\%) and the second (22.64\%) breeding periods, confirming the higher level of brood reduction in the case of second annual clutches.

Additionally, our results showed that the degree of egg losses before hatching was larger than the loss of nestlings after hatching in both the first and second annual clutches, and this result is in agreement with those reported by Marti (1994) in northern Utah. Considering initial clutch sizes, the proportion of brood reduction was also higher in case of larger and smaller clutch sizes than the modal one, but the degree of brood reduction did not differ 
significantly in the comparison of initial clutch sizes. Nevertheless, higher level of brood reduction was reported in the case of large than in small brood size (Taylor 1994). Similar to the distribution of egg losses, Martínez and Lopez (1999) found that the partial loss of nestlings was typical in clutches with 4 or more eggs.

We found that, the average number of fledglings per nest varied in the same range in the first $(\bar{x}=4.49)$ and in the second $(\bar{x}=4.25)$ annual clutches as well as in the total annual breeding season $(\bar{x}=4.45)$. The range of average value of fledglings was similar in France (first: $\bar{x}=4.29$ and second clutches: $\bar{x}=4.8$ ) (Baudvin \& Jouaire 2001), in the Middle-East $(\bar{x}$ $=4.91)$ (Meyrom et al. 2008), in northern Utah (USA) (first: $\bar{x}=5.09$ and second clutches: $\bar{x}$ $=4.94)$, and in north central Utah (USA) $(\bar{x}=4.0)$ (Looman et al. 1996), while it was higher in the Czech Republic (first: $\bar{x}=4.62$ and second clutches: $\bar{x}=6.75$ ) (Poprach 1996) and lower in British Columbia $(\bar{x}=3.4)$ (Andrusiak \& Cheng 1997), in Africa $(\bar{x}=3.19)$ (Wilson et al. 1986) and in Malaysia $(\bar{x}=3.7)$ (Lenton 1984). There was no significant difference in the amount of fledglings between the two annual breeding periods in our investigated area. However, we found that calculated fledging success was greater in the first than in the second annual clutches. The lack of significant difference in the numbers of young fledged between two annual breeding periods was reported from the USA (Marti 1994), however, no significant difference was found in the case of fledging success in the Spanish Mediterranean area (Martínez \& Lopez 1999).

Regarding brood size at fledging in relation to initial clutch size, the percentage value of fledging success was lower in modal clutch size while higher values of this breeding parameter were typical in the case of larger clutch sizes in our study area. Our results showed that, larger clutch sizes were more productive than the modal clutch size which in the first approach support the general hypothesis that the most productive clutch size is larger than the most frequent (Klomp 1970, Perrins \& Moss 1975, Stearns 1976). In contrast, modal clutch size (5 eggs) was the most productive in the Mediterranean region in Spain (Martínez \& Lopez 1999) and in north central Utah (USA) where the modal and most productive clutch size was higher (7 eggs) (Looman et al. 1996), the same clutch size having been identified in the present study as the modal, but not the most productive for Southern Hungary. In addition, we found significant linear regression between clutch size and young fledged production per nest attempt. Similarly, the number of fledglings increased with clutch size in Switzerland (Frey et al. 2011). The results of these two long-term studies (24- and a 23-year datasets) seemed to support the general hypothesis.

In the case of the Spanish population, the authors suggested that the coincidence of modal and the most productive clutch size may be explained by the alternative hypothesis by Boyce and Perrins (1987) because in terms of adult survival, the reproductive costs were low or were not measurable with owls. According to this alternative hypothesis, the cost of reproduction is not a necessary and sufficient factor for the optimization of clutch size because it is beneficial for the birds in the long term to lay clutches smaller than the most productive clutch size (Boyce \& Perrins 1987). The low reproduction costs observed in Spain can be traced back to the lack of fluctuation of environmental variables, such as climate and food resources (availability of rodents) because variation in the reproductive parameters of the Common Barn-owl was not detected during the 7 years, the average laying 
date and clutch size did not differ between years (Martínez \& Lopez 1999). The coincidence of modal and the most productive clutch size was observed in a shorter study (6-year dataset) also in north central Utah (USA). However, this study detected significant variation in clutch size among the years (Looman et al. 1996). In contrast, Marti (1994) reported the lack of significant difference of clutch size among years and among nest sites during a 16-year sampling period. Conversely, our results showed that all observed and calculated breeding parameters for the whole annual breeding season varied significantly among the years. As already highlighted above in case of percentage values of nest box occupancy, the impact of extreme years ('good-year' or 'bad-year effect') influenced the reproductive output of the Common Barn-owl during the 24 years. The largest average value of clutch size, brood size, fledglings and productivity rate were detected in 2014, caused by the extreme population outbreak of the Common Vole (Microtus arvalis) (Pallas, 1778). The multiannual population cycles of the Common Vole were widely investigated (Jacob et al. 2014) and three-year-long population cycles were documented in Europe (Tkadlec \& Stenseth 2001, Lambin et al. 2006). Predominance of Common Vole was typical in diet of Barn Owls from the pellet analysis which was conducted in Baranya County (Horváth 1999, Horváth et al. 2018). The direct monitoring of Common Vole activity in the intensively used alfalfa fields in our investigated area was started in the collapse phase after the 2014 outbreak, based on counting reopened burrow entrances, and detected the next increasing phase of this rodent in 2017 (Somogyi \& Horváth 2019). Earlier studies of Common Barn-owl's breeding biology had already reported that the number of nesting and the proportion of double brood pairs as well as the values of reproductive output of owls were larger in the outbreak than in the non-outbreak periods of Common Vole (Schönfeld \& Girbig 1975, Kaus 1977, Baudvin 1979, de Brujin 1994). In contrast to this 'good-year effect', due to extreme large participation in the first clutches period, the highest proportion of egg loss, the lowest average value of brood size and hatching success, the higher degree of brood reduction, as well as the lowest rate of fledging success and annual productivity were detected in 2010, as a prominent negative impact ('bad-year effect'). Boyce and Perrins (1987) already emphasized the importance of long-term studies, since the impact of extreme years on clutch size optimization and the variation of reproductive outputs could not be detected without multi-annual dataset, also pointing out the Spanish study in the case of Common Barn-owl clutches. Although we have no data on the reproductive cost of the owls or the lack of it but our data seem to support the hypothesis of Boyce and Perrins (1987), because Common Barn-owls laid more often smaller clutches than most productive ones in our investigated area in South-Hungary where the fluctuating environment was typical. While in the case of Spanish population, due to the more stable environment, the variance of reproductive success was not typical and thus modal clutch size was the same as the most productive clutch size (Martínez \& Lopez 1999). In this study, we had no purpose to examine the effect of environmental variables, however, based on our long term dataset, it is necessary to test the impact of weather parameters and small mammals, particularly the Common Vole as the main prey, on the reproductive output of the Common Barn-owl.

Among the breeding parameters, we emphasize the results of three variables such as egg loss, hatching success and annual productivity. During the 24 years, the rate of egg loss 
showed decline with significant negative linear trend while hatching success increased with significant positive linear trend. Based on the distribution of annual productivity rate 2.5 - 3.5 fledglings per nesting attempt were calculated most frequently for the whole annual breeding periods and we did not find significant difference of productivity between the first and second annual clutches which result is consistent with the study by Martínez and Lopez (1999). Similar productivity rate $(\bar{x}=3.5)$ was calculated in north central Utah (Looman et al. 1996) which average value is equal to the upper limit of the most common annual productivity range of investigated Hungarian Common Barn-owl population. Nevertheless, lower average productivity $(\bar{x}=2.7)$ was detected in the agricultural landscape of British Columbia (Hindmarch et al. 2014), however this value was similar to the lower limit of the most frequent annual productivity range which we calculated in our investigated area. The Canadian study suggested that food availability was reduced in more urbanized landscapes which lead to a higher degree of brood reduction and thus low productivity in Common Barn-owls (Hindmarch et al. 2014). Additionally, considering complete annual breeding seasons, the annual variation of productivity showed significant, slightly positive linear trend during the 24 years.

Although the monitoring of the Common Barn-owl's breeding biology was conducted in the continental region of European temperate zone in Southern Hungary, our results were compared to studies of different geographical and climatic zones where the environmental variability and the availability of food resources differs from those found in our study area. Considering all of the above, the comparative evaluation suggested that the optimization of clutch size for the stable or variable environment is an evolutionarily stable strategy of Common Barn-owls to maximize its lifetime reproductive success. In the light of our findings, despite the outlier values of reproduction characteristics in the extreme years with negative effect, a relatively stable regional Common Barn-owl population can be maintained by the placement of nest boxes in the investigated Southern Hungarian region.

\section{Acknowledgments}

We thank the Churches of Baranya County, especially the Bishopric of Pécs and Reformed congregations for providing opportunity to place nest boxes. The members of the Baranya County Group of BirdLife Hungary and the enthusiastic volunteers of 'Foundation for Natural Resources in Baranya' provided their generous help in the monitoring, cleaning and maintenance the nest boxes. We would also like to thank the cooperation of the local parish priests, parsons, pastors, church janitors, presbyters and bell-ringers. Finally, we would like to thank the anonymous reviewers for many helpful and constructive comments on the manuscript. 


\section{References}

Albert, C. A., Wilson, L. K., Mineau, P., Trudeau, S. \& Elliott, J. E. 2010. Anticoagulant rodenticides in three owl species from western Canada, 1988-2003. - Archives of Environmental Contamination and Toxicology 58(2): 451-459. DOI: 10.1007/s00244-009-9402-z

Almasi, B., Béziers, P., Roulin, A. \& Jenni, L. 2015. Agricultural land use and human presence around breeding sites increase stress-hormone levels and decrease body mass in Barn Owl nestlings. - Oecologia 179(1): 89101. DOI: $10.1007 / \mathrm{s} 00442-015-3318-2$

Altwegg, R., Schaub, M. \& Roulin, A. 2006a Age-specific fitness components and their temporal variation in the Barn Owl. - American Naturalist 169: 47-61. DOI: 10.1086/510215

Altwegg, R., Roulin, A. \& Kestenholz, M. 2006b Demographic effects of extreme winter weather in the Barn Owl. - Oecologia 149: 44-51. DOI: 10.1007/s00442-006-0430-3

Andrusiak, L. A. \& Cheng, K. M. 1997. Breeding biology of the Barn Owl (Tyto alba) in the Lower Mainland of British Columbia. - In: Duncan, J. R., Johnson, D. H. \& Nicholls, T. H. (eds.) Biology and conservation of owls in the Northern Hemisphere. Second international symposium. MA USDA Forest Service General Technical Report NC-190, Winnipeg, pp. 38-46.

Arlettaz, R., Krähenbühl, M., Almasi, B., Roulin, A. \& Schaub, M. 2010. Wildflower areas within revitalized agricultural matrices boost small mammal populations but not breeding Barn Owls. - Journal of Ornithology 151: 553-564. DOI: 10.1007/s10336-009-0485-0

Askew, N. P., Searle, J. B. \& Moore, N. P. 2007. Prey selection in a Barn Owl Tyto alba: Capsule a breeding Barn Owl selected vole-rich habitats for hunting at both a microhabitat and landscape scale. - Bird Study 54(1): 130-132. DOI: 10.1080/00063650709461465

Bank, L. 1990. Az 1985-86. évi gyöngybagoly (Tyto alba Scop., 1769) felmérés eredményei Baranya megyében [Estimation of the Barn Owl (Tyto alba Scop., 1769) population in Baranya county, 1985-1986]. - Aquila 9697: 113-126. (in Hungarian with English Summary)

Baudvin, H. 1978. Le cannibalisme chez l'Effraie Tyto alba [Cannibalism at the Barn Owl Tyto alba]. - Nos Oiseaux 34: 223-231. (in French)

Baudvin, H. 1979. Les secondes nichées chex la Chouette Effraie (Tyto alba) en Conte-d'Or [The second clutches of the Barn Owl Tyto alba]. - Nos Oiseanx 35: 125-134. (in French)

Baudvin, H. 1986. La reproduction de la Chouette Effraie (Tyto alba) [The reproduction of the Barn Owl (Tyto alba)]. - Le Jean-la-Blanc 25: 1-125. (in French)

Baudvin, H. \& Jouaire, S. 2001. Breeding biology of the Barn Owl (Tyto alba) in Burgundy (France): a 25 year study (1971-1995). - Buteo 12: 5-12.

Béziers, P. \& Roulin, A. 2016. Double brooding and offspring desertion in the Barn Owl Tyto alba. - Journal of Avian Biology 47(2): 235-244. DOI: 10.1111/jav.00800

BirdLife International 2004. Birds in Europe: Population Estimates, Trends and Conservation Status. - BirdLife International, Cambridge, U.K.

Bond, G., Burnside, N. G., Metcalfe, D. J., Scott, D. M. \& Blamire, J. 2005. The effects of land-use and landscape structure on Barn Owl (Tyto alba) breeding success in southern England, UK. - Landscape Ecology 20(5): 555-566. DOI: 10.1007/s10980-004-5037-7

Borda-de-Água, L., Grilo, C. \& Pereira, H. M. 2014. Modeling the impact of road mortality on Barn Owl (Tyto alba) populations using age-structured models. - Ecological Modelling 276: 29-37. DOI: 10.1016/j.ecolmodel.2013.12.022

Boves, T. J. \& Belthoff, J. R. 2012. Roadway mortality of Barn Owls in Idaho, USA. - The Journal of Wildlife Management 76(7): 1381-392. DOI: 10.1002/jwmg.378

Boyce, M. S. \& Perrins, C. M. 1987. Optimizing Great Tit clutch size in a fluctuating environment. - Ecology 68(1): 142-153. DOI: $10.2307 / 1938814$

Braaksma, S. \& de Bruijn, O. 1976. De kerkuilstand in Nederland. - Limosa 49: 135-187.

Bunn, D. S., Warburton, A. B. \& Wilson, R. D. S. 1982. The Barn Owl. - T \& AD Poyser, London, U.K.

Charter, M., Izhaki, I. \& Leshem, Y. 2010a Effects of the risk of competition and predation on large secondary cavity breeders. - Journal of Ornithology 151(4): 791-795. DOI: 10.1007/s10336-010-0514-Z

Charter, M., Meyrom, K., Leshem, Y., Aviel, S., Izhaki, I. \& Motro, Y. 2010b Does nest box location and orientation affect occupation rate and breeding success of Barn Owls Tyto alba in a semi-arid environment? - Acta Ornithologica 45: 115-119. DOI: 10.3161/000164510X516164 
Charter, M., Leshem, Y., Meyrom, K., Peleg, O. \& Roulin, A. 2012. The importance of micro-habitat in the breeding of Barn Owls Tyto alba. - Bird Study 59(3): 368-371. DOI: 10.1080/00063657.2012.669360

Charter, M., Izhaki, I., Leshem, Y., Meyrom, K. \& Roulin, A. 2015. Relationship between diet and reproductive success in the Israeli Barn Owl. - Journal of Arid Environments 122: 59-63. DOI: 10.1016/j.jaridenv.2015.06.011

Charter, M., Izhaki, I., Meyrom, K., Aviel, S., Leshem, Y. \& Roulin, A. 2017. The relationship between weather and reproduction of the Barn Owl Tyto alba in a semi-arid agricultural landscape in Israel. - Avian Biology Research 10(4): 253-258. DOI: 10.3184/175815617X15063340995365

Chausson, A., Henry, I., Almasi, B. \& Roulin, A. 2014a Barn Owl (Tyto alba) breeding biology in relation to breeding season climate. - Journal of Ornithology 155(1): 273-281. DOI: 10.1007/s10336-013-1012-x

Chausson, A., Henry, I., Ducret, B., Almasi, B. \& Roulin, A. 2014b Tawny Owl Strix aluco as an indicator of Barn Owl Tyto alba breeding biology and the effect of winter severity on Barn Owl reproduction. - Ibis 156(2): 433441. DOI: $10.1111 /$ ibi.12148

Colvin, B. A. 1985. Common Barn-owl population decline in Ohio and the relationship to agricultural trends. - Journal of Field Ornithology 56(3): 224-235.

de Bruijn, O. 1994. Population ecology and conservation of the Barn Owl Tyto alba in farmland habitats in Liemers and Achterhoek (The Netherlands). - Ardea 82: 1-109. DOI: 10.5253/078.097.0407

David, P. G. 1996. Nesting and food habitats of Barn Owls in south Florida. -The Florida Field Naturalist 24: 93-100.

De Jong, J. 2009. The recovery of the Barn Owl Tyto alba in Friesland, northern Netherlands: population growth in relation to landscape features. - Ardea 97(4): 445-453. DOI: 10.5253/078.097.0407

De Jong, J., van den Burg, A. \& Liosi, A. 2018. Determinants of traffic mortality of Barn Owls (Tyto alba) in Friesland, The Netherlands. - Avian Conservation and Ecology 13(2): 2. DOI: 10.5751/ACE-01201-130202

Fajardo, I. 2001. Monitoring non-natural mortality in the Barn Owl (Tyto alba), as an indicator of land use and social awareness in Spain. - Biological Conservation 97(2): 143-149. DOI: 10.1016/S0006-3207(00)00091-4

Frey, C., Sonnay, C., Dreiss, A. \& Roulin, A. 2011. Habitat, breeding performance, diet and individual age in Swiss Barn Owls (Tyto alba). - Journal of Ornithology 152: 279-290. DOI: 10.1007/s10336-010-0579-8

Geduhn, A., Esther, A., Schenke, D., Gabriel, D. \& Jacob, J. 2016. Prey composition modulates exposure risk to anticoagulant rodenticides in a sentinel predator, the Barn Owl. - Science of the Total Environment 544: 150-157. DOI: $10.1016 /$ j.scitotenv.2015.11.117

Gill, F. \& Donsker, D. 2018. IOC World Bird List (v 8.1). - DOI: 10.14344/ioc.ml.8.1.

Golawski, A., Kasprzykowski, Z. \& Kowalski, M. 2003. The occurrence of the Barn Owl Tyto alba in sacred buildings in central-eastern Poland. - Ornis Hungarica 12-13: 275-279.

Gray, A., Eadsforth, C. V., Dutton, A. J. \& Vaughan, J. A. 1994. The toxicity of three second-generation rodenticides to Barn Owls. - Pest Management Science 42(3): 179-184. DOI: 10.1002/ps.2780420307

Gubanyi, J. A., Case, R. M. \& Wingfield, G. 1992. Diet and nesting success of Barn Owls breeding in western Nebraska. - American Midland Naturalist 127: 224-232. DOI: 10.2307/2426528

Hamilton, K. 1980. Cannibalism and possible fratricide in juvenile Barn Owls. - Texas Journal of Science 32(2): $175-175$.

Heath, M., Borggreve, C., Peet, N. \& Hagemeijer, W. 2000. European Bird Populations: Estimates and Trends. Birdlife Conservation Series No. 10. Birdlife International, Cambridge, U.K.

Hindmarch, S., Krebs, E. A., Elliott, J. E. \& Green, D. J. 2012. Do landscape features predict the presence of Barn Owls in a changing agricultural landscape? - Landscape and Urban Planning 107(3): 255-262. DOI: 10.1016/j. landurbplan.2012.06.010

Hindmarch, S., Krebs, E. A., Elliott, J. \& Green, D. J. 2014. Urban development reduces fledging success of Barn Owls in British Columbia, Canada. - The Condor: 116(4): 507-517. DOI: 10.1650/CONDOR-13-052.1

Horváth, G. 1999. A gyöngybagoly (Tyto alba Scop., 1769) köpetvizsgálatának tíz éve Baranya megyében (19851994) [Ten years of Barn Owl (Tyto alba Scop., 1769) pellet analysis in county Baranya (1985-1994)]. - Állattani Közlemények 84: 63-77. (in Hungarian with English Summary)

Horváth, A., Morvai, A. \& Horváth, G. F. 2018. Food-niche pattern of the Barn Owl (Tyto alba) in intensively cultivated agricultural landscape. - Ornis Hungarica 26(1): 27-40. DOI: 10.1515/orhu-2018-0002

Hope, R. M. 2016. Rmisc: Ryan miscellaneous. R package version 1.5. URL: https:/CRAN.R-project.org/package $=$ Rmisc

Jacob, J., Manson, P., Barfknecht, R. \& Fredricks, T. 2014. Common Vole (Microtus arvalis) ecology and management: implications for risk assessment of plant protection products. - Pest Management Science 70(6): 869-878. DOI: 10.7325/Galemys.2016.A2 
Johnson, P. N. 1994. Selection and use of nest sites by Barn Owls in Norfolk, England. - Journal of Raptor Research 28(3): 149-153.

Kan, I., Motro, Y., Horvitz, N., Kimhi, A., Leshem, Y., Yom-Tov, Y. \& Nathan, R. 2013. Agricultural rodent control using Barn Owls: is it profitable? - American Journal of Agricultural Economics 96(3): 733-752. DOI: 10.1093/ajae/aat097

Kassinis, N. \& Roulin, A. 2017. Reproduction of the Barn Owl (Tyto alba) in Cyprus (Aves: Strigiformes). - Zoology in the Middle East 63(4): 369-371. DOI: 10.1080/09397140.2017.1331588

Klein, Á., Nagy, T., Csörgő, T. \& Mátics, R. 2007. Exterior nest-boxes may negatively affect Barn Owl Tyto alba survival: an ecological trap. - Bird Conservation International 17(3): 273-281. DOI: 10.1017/ S0959270907000792

Klok, C. \& De Roos, A. M. 2007. Effects of vole fluctuations on the population dynamics of the Barn Owl Tyto alba. - Acta Biotheoretica 55: 227-241. DOI: 10.1007/s10441-007-9013-x

Klomp, H. 1970. The determination of clutch-size in birds a review. - Ardea 55(1-2): 1-125.

Kross, S. M., Bourbour, R. P. \& Martinico, B. L. 2016. Agricultural land use, Barn Owl diet, and vertebrate pest control implications. - Agriculture, Ecosystems \& Environment 223: 167-174. DOI: 10.1016/j.agee.2016.03.002

Kaus, D. 1977. Zur Populationsdynamik, Ökologie und Brutbiologie der Schleiereule Tyto alba in Franken [On the population dynamics, ecology and breeding biology of the Barn Owl Tyto alba in Franconia]. - Anzeiger der Ornithologische Gesellschaft in Bayern 16: 18-44. (in German with English Summary)

Lack, D. 1947. The significance of clutch-size. I and II. - Ibis 89: 302-352. DOI: 10.1111/j.1474-919X.1947. tb04155.x

Lack, D. 1954. The Natural Regulation of Animal Numbers. - Clarendon Press, Oxford

Lambin, X., Bretagnolle, V. \& Yoccoz, N. G. 2006. Vole population cycles in northern and southern Europe: is there a need for different explanations for single pattern? - Journal of Animal Ecology 75: 340-349. DOI: 10. 1111/j.1365-2656.2006.01051.x

Leech, D. I., Shawyer, C. R., Barimore, C. J. \& Crick, H. Q. P. 2009. The Barn Owl monitoring programme: establishing a protocol to assess temporal and spatial variation in productivity at a national scale. - Ardea 97: 421428. DOI: $10.5253 / 078.097 .0404$

Lemon, J. 2006. Plotrix: a package in the red light district of R. - R-News 6: 8-12.

Lenton, G. M. 1984. The feeding and breeding ecology of Barn Owls Tyto alba in peninsular Malaysia. - Ibis 126(4): 551-575. DOI: 10.1111/j.1474-919X.1984.tb02080.x

Liébana, M. S., Sarasola, J. H. \& Santillán, M. Á. 2013. Nest-box occupancy by neotropical raptors in a native forest of central Argentina. - Journal of Raptor Research 47(2): 208-214. DOI: 10.3356/JRR-12-51.1

Looman, S. J., Shirley, D. L. \& White, C. M. 1996. Productivity, food habits, and associated variables of Barn Owls utilizing nest boxes in north central Utah. - Great Basin Naturalist 56(1): 73-84.

Mahmood-Ul-Hassan, M., Beg, M. A., Mushtaq-Ul-Hassan, M., Mirza, H. A. \& Siddique, M. 2007. Nesting and diet of the Barn Owl (Tyto alba) in Pakistan. - Journal of Raptor Research 41(2): 122-130. DOI: 10.3356/0892-1016(2007)41[122:NADOTB]2.0.CO;2

Mainwaring, M. C. 2011. The use of nestboxes by roosting birds during the non-breeding season: a review of the costs and benefits. - Ardea 99(2): 167-177. DOI: 10.5253/078.099.0206

Mainwaring, M. C. 2015. The use of man-made structures as nesting sites by birds: A review of the costs and benefits. - Journal for Nature Conservation 25: 17-22. DOI: 10.1016/j.jnc.2015.02.007

Marti, C. D. 1994. Barn Owl reproduction: patterns and variation near the limit of the species' distribution. - The Condor 96(2): 468-484. DOI: 10.2307/1369329

Marti, C. D. 1997. Lifetime reproductive success in Barn Owls near the limit of the species' range. - The Auk 114(4): 581-592. DOI: 10.2307/4089277

Marti, C. D., Wagner, P. W. \& Denne, K. W. 1979. Nest boxes for the management of Barn Owls. - Wildlife Society Bulletin 7(3): 145-148.

Marti, C. D. \& Wagner, P. W. 1985. Winter mortality in Common Barn-owls and its effect on population density and reproduction. - The Condor 87(1): 111-115. DOI: 10.2307/1367142

Martin, J. M., Branch, L. C., Raid, R. N. \& Beyeler, S. C. 2010. Temporal instability of agricultural habitat reduces reproductive success of Barn Owl s (Tyto alba). - Auk 127: 909-916. DOI: 10.1525/auk.2010.09211

Martínez, J. A. \& López, G. 1999. Breeding ecology of the Barn Owl (Tyto alba) in Valencia (SE Spain). - Journal für Ornithologie 140(1): 93-99. DOI: 10.1007/BF02462093

Martínez, J. A. \& Zuberogoitia, I. 2004. Habitat preferences and causes of population decline for Barn Owls Tyto alba: a multi-scale approach. - Ardeola 51(2): 303-317. 
Mátics, R., Bank, L., Varga, S., Klein, A. \& Hoffmann, G. 2008. Interspecific offspring killing in owls. - Biological Journal of the Linnean Society 95(3): 488-494. DOI: 10.1111/j.1095-8312.2008.01064.x

Mátics, R., Hoffmann, G., Farkas, S., Dawson, D., Frantz, A., Varga, D., Mátics, E. \& Klein, Á. 2017. Demographic decline and detection of genetic bottleneck in a population of Barn Owl Tyto alba in Hungary. - Journal of Ornithology 158(3): 811-821. DOI: 10.1007/s10336-017-1433-z

McCafferty, D. J., Moncrieff, J. B. \& Taylor, I. R. 2001. How much energy do Barn Owls (Tyto alba) save by roosting? - Journal of Thermal Biology 26: 193-203. DOI: 10.1016/S0306-4565(00)00042-5

Meek, W. R., Burman, P. J., Nowakowski, M., Sparks, T. H., Hill, R. A., Swetnam, R. D. \& Burman, N. J. 2009. Habitat does not influence breeding performance in a long-term Barn Owl Tyto alba study. - Bird Study 56(3): 369-380. DOI: 10.1080/00063650902937339

Meyrom, K., Leshem, Y. \& Charter, M. 2008. Barn Owl Tyto alba breeding success in man-made structures in the Jordan Rift valley, Israel. - Sandgrouse 30: 134-137.

Meyrom, K., Motro, Y., Leshem, Y., Aviel, S., Izhaki, I., Argyle, F. \& Charter, M. 2009. Nest-box use by the Barn Owl Tyto alba in a biological pest control program in the Beit She'an valley, Israel. - Ardea 97(4): 463-468. DOI: $10.5253 / 078.097 .0410$

Milchev, B. \& Gruychev, G. 2014. Breeding distribution and nest site diversity of Barn Owl (Tyto alba) in the context of restoration of agricultural sector in Central South Bulgaria. - Ornis Hungarica 22(1): 69-75. DOI: 10.2478/orhu-2014-0012

Mock, D. W. 1985. Siblicidal brood reduction: the prey-size hypothesis. - The American Naturalist 125(3): 327343. DOI: $10.1086 / 284346$

Møller, A. P. 1994. Facts and artefacts in nest-box studies: implications for studies of birds of prey. - Journal of Raptor Research 28: 143-148.

Müller, Y. 1990. Chevauchement des nidifications successives chez la Chouette Effraie (Tyto aba) [Overlap of successive breeding attempts in the Barn Owl (Tyto aba)]. - Alauda 58: 217-220. (in French with English Summary)

Newton, I., Wyllie, I., Gray, A. \& Eadsforth, C. V. 1994. The toxicity of the rodenticide flocoumafen to Barn Owls and its elimination via pellets. - Pest Management Science 41(3): 187-193. DOI: 10.1002/ps.2780410304

Partridge, L. \& Harvey, P. H. 1988. The ecological context of life history evolution. - Science 241: 1449-1455. DOI: $10.1126 /$ science.241.4872.1449

Pavluvčík, P., Poprach, K., Machar, I., Losík, J., Gouveia, A. \& Tkadlec, E. 2015. Barn Owl productivity response to variability of vole populations. - PloS One 10(12): e0145851. DOI: 10.1371/journal.pone.0145851

Paz, A., Jareño, D., Arroyo, L., Viñuela, J., Arroyo, B., Mougeot, F., Luque-Larena, J. J. \& Fargallo, J. A. 2013. Avian predators as a biological control system of Common Vole (Microtus arvalis) populations in north-western Spain: experimental set-up and preliminary results. - Pest Management Science 69(3): 444-450. DOI: 10.1002/ps.3289

Percival, S. M. 1991. Population trends in British Barn Owls: a review of some possible causes. - British Wildlife 2: 131-140.

Perrins, C. M. \& Moss, D. 1975. Reproductive rates in the Great Tit. - Journal of Animal Ecology 44(3): 695706. DOI: $10.2307 / 3712$

Petty, S. J., Shaw, G. \& Anderson, D. I. K. 1994. Value of nest boxes for population studies and conservation of owls in coniferous forests in Britain. - Journal of Raptor Research 28(3): 134-142.

Poprach, K. 1996. Hnízdní biologie a zmeny pocetnosti sovy pálené (Tyto alba) v okrese Olomouc [Breeding biology and changes in abundance of Barn Owl (Tyto alba) in Olomouc district (Czech Republic)]. - Buteo 8: 39-80. (in Czech with English Summary)

R Core Team 2017. R: A Language and Environment for Statistical Computing. - R Foundation for Statistical Computing, Vienna, Austria. URL: https://www.R-project.org/

Radley, P. M. \& Bednarz, J. C. 2005. Artificial nest structure use and reproductive success of Barn Owls in northeastern Arkansas. - Journal of Raptor Research 39(1): 74-79.

Roulin, A. 2002a Barn Owl. - BWP Update: Journal of the Birds of the Western Palearctic 4: 115-138. DOI: 10.1007/0-306-47660-6_6

Roulin, A. 2002b Short-and long-term fitness correlates of rearing conditions in Barn Owls Tyto alba. - Ardea 90(2): 259-267.

Roulin, A. 2002c The sibling negotiation hypothesis. - In: Wright, J. \& Leonard, M. L. (eds.) The Evolution of Begging: Competition, Cooperation and Communication, Dordrecht: Kluwer Academic, pp. 107-126. 
Roulin, A. 2004. Effects of hatching asynchrony on sibling negotiation, begging, jostling for position and within-brood food allocation in the Barn Owl Tyto alba. - Evolutionary Ecology Research 6(7): 1083-1098.

Roulin, A. \& Dreiss, A. N. 2012. Sibling competition and cooperation over parental care. - In: Royle, N. R., Smiseth, P. R. \& Kölliker, M. (eds.) The evolution of parental care. Oxford University Press, pp. 133-149.

Roulin, A., Ducrest, A. L. \& Dijkstra, C. 1999. Effect of brood size manipulations on parents and offspring in the Barn Owl Tyto alba. - Ardea 87: 91-100.

Roulin, A., Dijkstra, C., Riols, C. \& Ducrest, A. L. 2001. Female- and male-specific signals of quality in the Barn Owl. - Journal of Evolutionary Biology 14(2): 255-266. DOI: 10.1046/j.1420-9101.2001.00274.x

Sárossy, M. 2000. Ku hniezdeniu a migrácii plamienky driemavej (Tyto alba) na Slovensku [On breeding and movements of the Barn Owl (Tyto alba) in Slovakia]. - Buteo 11: 25-34. (in Czech with English Summary)

Sasvári, L. \& Hegyi, Z. 2011. Age-related territory occupation and fledgling production of males in a Central-European local population of Tawny Owls, Strix aluco. - Folia Zoologica 60(3): 221-228. DOI: 10.25225/fozo. v60.i3.a6.2011

Šálek, M., Poprach, K., Opluštil, L., Melichar, D., Mráz, J. \& Václav, R. 2019. Assessment of relative mortality rates for two rapidly declining farmland owls in the Czech Republic (Central Europe). - European Journal of Wildlife Research 65(1): 19. DOI: 10.1007/s10344-019-1253-y

Schönfeld, M. \& Girbig, G. 1975. Beiträge zur Brutbiologie der Schleiereule, Tyto alba, unter besonderer Berücksichtigung der Abhängigkeit von der Feldmausdichte [Contribution to the breeding biology of the Barn Owl, Tyto alba, with special regard to the dependence on field density]. - Hercynia 12(3): 257-319.

Sokal, R. R. \& Rohlf, F. J. 1997. Biometry. - W. H. Freeman and Co., New York

Somogyi, B. A. \& Horváth, G. F. 2019. Seasonal activity of Common Vole (Microtus arvalis) in alfalfa fields in southern Hungary. - Biologia 74(1): 91-96. DOI: 10.2478/s11756-018-0149-8

Stearns, S. C. 1976. Life-history tactics: a review of the ideas. - Quarterly Review of Biology 51: 3-47. DOI: 10.1086/409052

Steenhof, K. 1987. Assessing raptor reproductive success and productivity. - In: Giron Pendleton, B. A., Millsap, B. A., Cline, K. W. \& Bird, D. M. (eds.) Raptor management techniques manual. - National Wildlife Federation, Washington, DC U.S.A., pp. 157-170.

Steenhof, K. \& Newton, I. 2007. Assessing nesting success and productivity. - In: Bird, D. M. \& Bildstein, K. L. (eds.) Raptor Research and Management Techniques. - Surrey: Hancock House publishers LTD., pp. 181162.

Stenning, M. J. 1996. Hatching asynchrony, brood reduction, and other rapidly reproducing hypotheses. - Trends in Ecology \& Evolution 11: 243-246. DOI: 10.1016/0169-5347(96)10030-6

Stoleson, S. H. \& Beissinger, S. R. 1995. Hatching asynchrony and the onset of incubation in birds, revisited: when is the critical period? - In: Power, D. M. (ed.) Current Ornithology 12. Plenum, New York, pp. 191270. DOI: $10.1007 / 978-1-4615-1835-8 \_6$

Taylor, I. R. 1992. An assessment of the significance of annual variations in snow cover in determining short-term population changes in Field Voles Microtus agrestis and Barn Owls Tyto alba in Britain. - In: Galbraith, C. A., Taylor, I. R. \& Percival, S. (eds.) The ecology and conservation of European owls. - UK Nature Conservation No. 5, Joint Nature Conservation Committee, Peterborough, U.K. pp. 32-38.

Taylor, I. 1994. Barn Owls. Predator-prey relationships and conservation. - Cambridge University Press, Cambridge

Tkadlec, E. \& Stenseth, N. C. 2001. A new geographical gradient in vole population dynamics. - Proceedings of the Royal Society of London, Series B: Biological Sciences 268(1476): 1547-1552. DOI: 10.1098/ rspb.2001.1694

Toms, M. P., Crick, H. Q. \& Shawyer, C. R. 2001. The status of breeding Barn Owls Tyto alba in the United Kingdom 1995-97. - Bird Study 48(1): 23-37. DOI: 10.1080/00063650109461200

Tóth, Z., Horváth, G., \& Müller, E. 2005. Investigation of the mortality of a local Barn Owl population using key factor analysis. - Italian Journal of Zoology 72(3): 229-234. DOI: 10.1080/11250000509356676

Wendt, C. A. \& Johnson, M. D. 2017. Multi-scale analysis of Barn Owl nest box selection on Napa Valley vineyards. - Agriculture, Ecosystems \& Environment 247: 75-83. DOI: 10.1016/j.agee.2017.06.023

Wilson, R. T., Wilson, M. P. \& Durkin, J. W. 1986. Breeding biology of the Barn Owl (Tyto alba) in Central Mali. - Ibis 128(1): 81-90. DOI: 10.1111/j.1474-919X.1986.tb02095.x 